\title{
SÂNCRAIU DE MUREȘ (MAROSSZENTKIRÁLY): MEDIEVAL SETTLEMENT NETWORK, PAULINE MONASTERY AND ITS ENVIRONMENT ON THE MIDDLE COURSE OF THE MUREŞ RIVER
}

\author{
ELEK BENKŐ* - PÁL SÜMEGI** - TÜNDE TÖRŐCSIK - ELVIRA BODOR - BALÁZS SÜMEGI - \\ GUSZTÁV JAKAB*** \\ * Research Centre for the Humanities, Institute of Archaeology \\ Tóth Kálmán str 4, H-1097 Budapest, Hungary \\ benko.elek@btk.mta.hu \\ ** University of Szeged, Department of Geology and Palaeontology \\ Egyetem Str 2-6, H-6722 Szeged, Hungary \\ sumegi@geo.u-szeged.hu \\ *** Szent István University, Institute of Irrigation and Water Management \\ Szabadság Str 1-3, H-5540 Szarvas, Hungary \\ jakab.gusztav@gk.szie.hu
}

\begin{abstract}
The study aims to contribute to the medieval environmental history of the eastern periphery of the Transylvanian Plain (Câmpia Transilvaniei/Mezőség). With the help of archaeological and historical data and the multi-aspect analysis of undisturbed core sequences, the economic life of the Pauline Monastery founded in the $14^{\text {th }}$ century near Sâncraiu de Mureş (Marosszentkirály) and the surrounding villages was investigated. The multidisciplinary research focuses on the paleochannels of the Mureş and the artificial watercourses (ditches) that branch off the river, and the mills built on them. The work also provides new data on the general environmental changes in the middle course of the Mureş river during the Middle Ages and the early modern period, which are largely due to the very intense human activity here.
\end{abstract}

Keywords: Middle Ages, Pauline monastery, water mills, palynology, geochemistry, macrofossils, Transylvania

\section{INTRODUCTION}

The widening section of the Mureş (Maros) valley below Târgu Mureş (Marosvásárhely) is an area highly significant in terms of medieval settlement history and archaeology with regard to both the Szeklers who moved here at the end of the Árpád period and the Transylvanian antecedents of this movement. The densely-populated valley section, with favourable environmental and climatic conditions - located where the medieval Transylvanian counties and Szeklerland meet, on the eastern edge of the Transylvanian Plain (Câmpia Transilvaniei/Mezőség) was also significant in the late medieval history of the region, as the establishment and the economic activities of a Pauline monastery, too, contributed to the changes in the environment. The palaeoenvironmental reconstruction of a filled up oxbow lake of the Malom-berek ('Mill grove') by Sâncraiu de Mureș (Marosszentkirály) provides a good illustration of the changes in landscape use, which took place during the formation of Hungarian settlements in the Árpád period. It is especially significant that during the environmental archaeological analysis, in the floodplain of a large river, we were able to identify a unique water management system developed during the Árpád period.

\section{HISTORICAL BACKGROUND}

Previous archaeological research suggests that in this western region as well of what became Szeklerland the settlement pattern was substantially altered during the Árpád period. Even if only approximately, the archaeological horizon dated to the first half of the Árpád period, prior to the settlement of the Szeklers, has become 
distinguishable. The remains of this horizon appear more densely precisely in the area of our present research, around Târgu Mureş (Marosvásárhely). Among the primarily village-like settlement remains, an exception is the Moreşti (Malomfalva) hillfort, which, following antecedents from the Gepid period, was also used during the first half of the Árpád period. It was likely the centre of an Árpád period territorial unit, which can no longer be identified. By the $13^{\text {th }}$ century, the stronghold lost its significance and became depopulated, presumably in connection with the settlement of the Szeklers and the late- $13^{\text {th }}$-century development of a nearby, new market town (Novum Forum Siculorum, what is now Târgu Mureş/Marosvásárhely). ${ }^{1}$ Numerous towns in the region, including the focus of our research, Sâncraiu de Mureș (Marosszentkirály), established churches in the second half of the Árpád period. ${ }^{2}$ We know the wealthy eponym of neighbouring Nazna (Náznánfalva), a Szekler man called Naznanus from a 1295 document, on account of his purchase of an expensive estate in Cluj (Kolozs) county. ${ }^{3}$ The aforementioned villages established mills already in the early stages of their existence, built along canals branching off from and rejoining the Mureş riverbed, with controllable water flow and greater protection from floods. The establishment of further mills became necessary due to the foundation of the Szentkirály Pauline monastery during the $14^{\text {th }}$ century as well as the local needs of smaller settlements with names ending in '-szeg' (Borzaszeg, Egerszeg, Remeteszeg) formed between the earlier villages of the region. These mills were frequently built in a line along the same, presumably dug, canal system. Our modern period sources also discuss the digging of such canals as well as the problems connected with the operation of dams and mills located one above the other.

The only Pauline monastery in Szeklerland during the Middle Ages, alternatingly referred to as the 'Szentkirály' or 'Székelyháza' monastery was founded, according to tradition, in 1370. In that year King Louis I ordered the Chapter of Transylvania to assign to the Pauline hermits the stone church of Saint Mary the Virgin on the hill above the village of Szentkirály, as well as certain ploughlands and forest tracts donated to them by László Tóth, László Bulgár (Bwlgar) and their relatives. ${ }^{4}$ Based on the names it is certain that the foundation and the endowment of the monastery were initiated by prominent Szeklers: the members of the Bulgár family of Szentkirály, and of the Tóth family with ties to neighbouring Sântana de Mureș (Marosszentanna). The two families are believed to have a common origin. The monastery was built on the hilltop rising above the wide Mureş valley (Fig. 1), near the road leading from Cluj (Kolozsvár) through the Transylvanian Plain to Târgu Mureş (Marosvásárhely). Its prominent location is clear from medieval sources, where it appears in several places with the designation in promontorio de Szent Kyraly. It has been raised that the monastery may have been founded earlier, ${ }^{5}$ namely Zsigmond Jakó identified a "Saint Paul" church (de Sancto Paulo) - mentioned in the papal tithe records for 1335 of the Maros diaconate of the Telegd archidiaconate - as the Pauline monastery of Szentkirály. ${ }^{6}$ Based on our current knowledge, however, we cannot resolve the issue in a satisfying way. Firstly, for an embryonic community - if they even had to pay the papal tithe at all - the four silver grossi paid by the custos of Sanctus Paulus seem too high a sum, compared to the tithe of the surrounding settlements. Secondly, we have no evidence based on which to suppose that the community of hermits was not located from the beginning in the Szentkirály area (where the founding Szekler notables, too, were living), but in a certain place called Sanctus Paulus/Szentpál. After all, the name 'Szentpál' never appears in the names of places where medieval Pauline monasteries were located; furthermore, the term custos, too, is not customarily used for medieval Paulines. In the Middle Ages the monastery was referred to as either the Szentkirály or Székelyháza monastery. It is problematic, however, that in the late medieval and early modern sources at our disposal we cannot find any Székelyháza, which appears in the name of the monastery. We can only find the disappeared village of Székelyfalva, which lay between Sâncraiu de Mureş (Marosszentkirály) and Târgu Mureş (Marosvásárhely), east of Remetea (Remeteszeg, the name of the settlement clearly refers to the Pauline hermits), and which repeatedly appears among the $14^{\text {th }}$ and $15^{\text {th }}$ century donations to the Paulines. The lands of the village Székelyfalva, destroyed by the early modern period, were absorbed by neighbouring Târgu Mureş. ${ }^{7}$ Locating it requires

\footnotetext{
${ }^{1}$ BENKŐ 2012, 78.

${ }^{2}$ In 1332 Petrus, the parish priest of Szentkirály, paid the papal tithe together with the priests of the Maros deanery of the Telegd archdeaconry. Based on the paid sum, Szentkirály can be considered one of the wealthier parishes of district Maros, EO II, 1143. In 1334 and 1335 the priest of Szentkirály paid an average or somewhat above-average sum. The tower of the church still contains Romanesque period details, BENKŐ 2012, 127.

${ }^{3}$ SzOkl VIII, 5-6; EO I, 525.
}

${ }^{4}$ 1370: Joannes Toth et Ladislaus Bulgar et sui fratres unanimi voto dederunt heremitis quandam ecclesiam lapideam in honore Virginis Marie fundatam super quodam monticulo versus villam Zenthkyral cum quibusdam terrarum arabilium et silvarum particulis dotatam, DAP 2/1976, 447; GYÖNGYÖSI 1988, 54; ENTZ 1996, 378; EO IV, 836.

$$
\begin{aligned}
& { }^{5} \text { BENKÖ 2012, 259-261. } \\
& { }^{6} \text { EO II, nr. 1146. } \\
& { }^{7} \text { SzTA 7/B, 661-662. }
\end{aligned}
$$



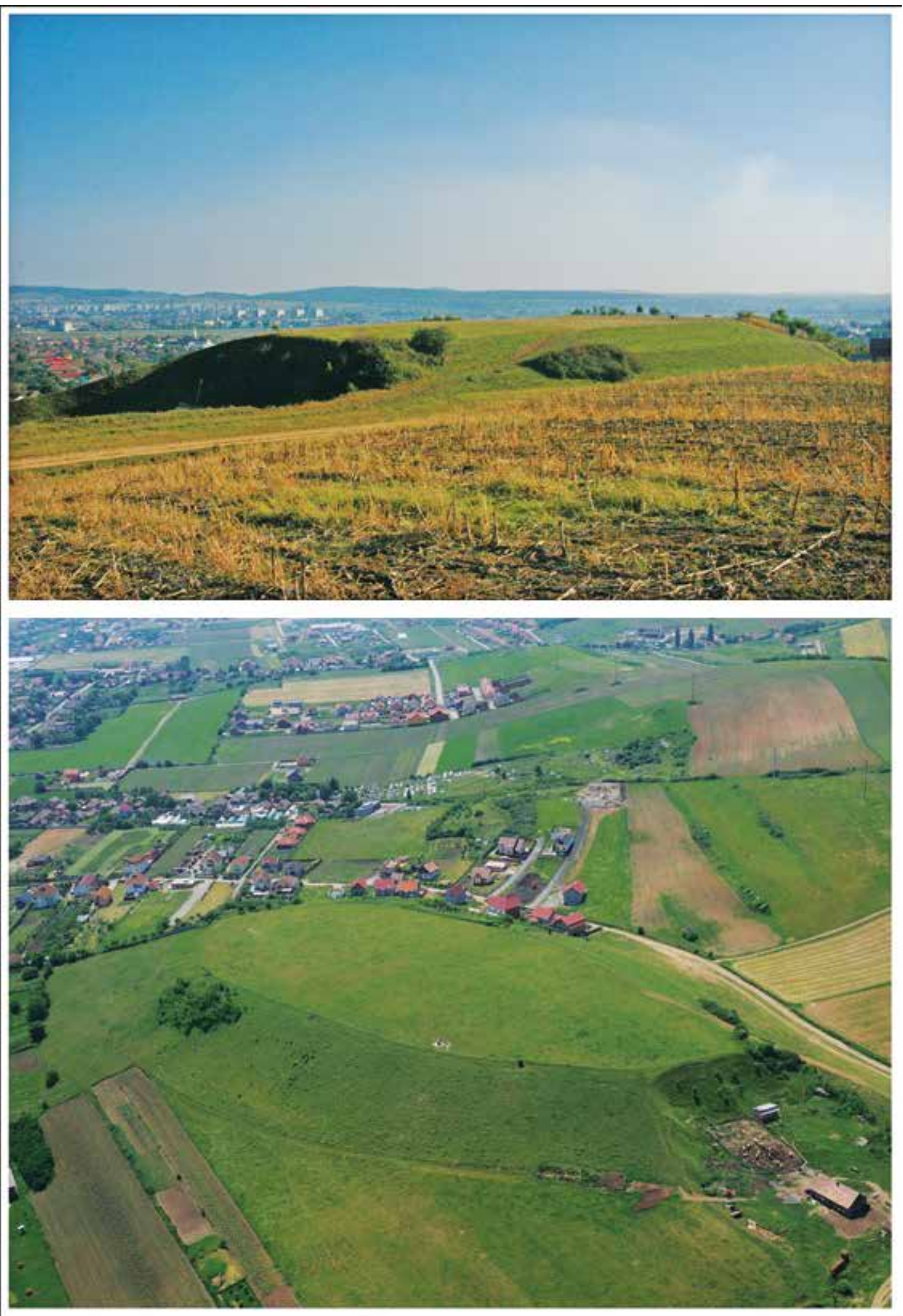

Fig. 1. Sâncraiu de Mureş, hilltop with the remains of the Pauline monastery that has not yet been studied by archeological research (Photo: Elek Benkő, Zoltán Czajlik) 
further archaeological research, as does answering the question: what was the original function of the aforementioned church of Saint Mary the Virgin donated to the Paulines?

Thanks to the numerous local land donations, the Pauline hermits who settled here quickly began to grow richer. In 1372, the founder, László Bulgár supplemented his original gift with a noble land next to the parish building (una curia in vicinitate curiae plebani ecclesiae Sancti Regis), a forest (Kyreserdeii) and a fish pond next to the village. ${ }^{8}$ In 1376 the hermits received a part of the Szentkirály forest (Gelyen Erdey), ${ }^{9}$ and then in 1378 they gained a mill-site below the Nazna (Náznánfalva) mill, including a site for the miller's house. ${ }^{10}$ This gift was followed in subsequent decades by other transactions, through which the Paulines received as gifts in the Sâncraiu de Mureş area further mills along the watercourse, which breaks off towards the north from and then rejoins the Mureş. Thus in 1380, in an area belonging to Székelyfalva (villa Siculorum), they gained a mill-site by the inner canal of the Mureş river, ${ }^{11}$ this was followed in 1382 by the Saturday income of another mill in Székelyfalva (in fossato fluvii Morwsii habiti), ${ }^{12}$ and in 1395 a part ownership in the nearby mill called 'the mill of Vince' ${ }^{13}$ In 1405 , the hermits received a grove and a meadow at the eastern edge of Sâncraiu de Mures (Marosszentkirály), between the Mureş river and a certain canal (presumably the repeatedly aforementioned millrace), ${ }^{14}$ which was followed in 1408 by a further parcel of land in Székelyfalva and a mill-site along a canal branching off from the Mureş river. ${ }^{15}$ In 1420 the Paulines gained another mill-site (super fluvio Marosarka in facie possessionis Zekelfalwa), as well as ploughlands and meadows. ${ }^{16}$ In 1448 mistress Margit, a relative of the Bulgárs of Szentkirály, gave the monastery half of the so-called "Egherzegh" mill (in minori fluvio Marosii) and ferry along with certain appendages. ${ }^{17}$ In 1489 an agreement was reached between the Paulines and Balázs Gyulakuti of Szentanna regarding the half of a mill in Székelyfalva (super fluvio Marosarok), fields and the so-called Kewzberk forest. ${ }^{18}$ In 1453 the Paulines reconstructed one of the watermills which they had received (in rivulo fluvii Moros vulgo Zeekes nominato). ${ }^{19}$ The mills built along the canal branching off from the main course of the Mureş, as well as the acquired sites suitable for mill building greatly improved the financial condition of the monastery. After all, the mills were not only workshops used for grinding grain; they also brought mill rights: others could not build new mills next to them and the Paulines made sure to assert their rights. ${ }^{20}$ We may reasonably assume that they ground grain not only to meet their own needs; the monastery required nowhere near as many mills for that. Those living in the region, too, likely brought their grain to these mills, which provided a constant income for the monastery.

In the decades following the monastery's foundation, in addition to the mills, the hermits also acquired nearby fields, meadows, vineyards and forests. From the description of the gifts it appears that, lying on the plain of the Mureş, the lower edge of the lands belonging to Szentkirály and the neighbouring villages was essentially unwooded, with fields, pastures and meadows as well as shrublands and groves.

The further rise of the visibly wealthy monastery was stopped by the Reformation. In 1556 the burghers of Târgu Mureş (Marosvásárhely), having converted to the new faith, seized the local parish church and drove out the Franciscans from their church. Probably in the same year or somewhat later, monastic life also came to an end at the nearby Szentkirály monastery. This, however, did not mean that life stopped in the immediate environs of the monastery or on its estates. As sixteenth-to-eighteenth-century documents attest, in this densely-populated area, agricultural production continued on monastery lands now in private hands, as did the use of mills built along the Mureş canals. ${ }^{21}$ The water flow rate in the canals was secured by dams built on the main branch of the Mureş. The watercourse, which powered the mill at the southern edge of Borzaszeg and Nazna (Náznánfalva), was called in 1746 the Kis-Maros ('Little Mureş') or Árok ('Canal'), and along it lay a field. ${ }^{22}$

\footnotetext{
${ }^{8}$ DAP 2/1976, 447.

${ }^{9}$ DAP 2/1976, 448.

${ }^{10}$ 1378: donavit quendam locum molendini in quodam fluvio seu fossato a Marwsyo decurrente, videlicet infra molendinum Nazan (!) vocatum habitum cum uno fundo pro domo molendinatoris necessario, DAP 2/1976, 447.

${ }^{11}$ 1380: in fluvio Moryzii in fossato interiori, in fine prati heremitarum Bodamezeye vocati, DAP 2/1976, 447.

${ }^{12}$ DAP 2/1976, 448.

13 1395: in quodam molendino Wyncze molna in fluvio fossati Morws Zekelpathaka vocato decurrenti, DAP 2/1976, 448.
}

Acta Archaeologica Academiae Scientiarum Hungaricae 71, 2020

\author{
${ }^{14}$ 1405: quandam particulam terrae videlicet rubetum cum \\ feneto Bodmezeye vocato inter fluvium Morws et quoddam fossatum \\ situatum: DAP 2/1976, 448. \\ ${ }^{15}$ DAP 2/1976, 448 \\ ${ }^{16}$ DAP 2/1976, 448. \\ ${ }^{17}$ DAP 2/1976, 449 \\ ${ }^{18}$ DAP 2/1976, 449 \\ ${ }^{19}$ DAP 2/1976, 449 \\ ${ }^{20}$ 1467: SzOKL VIII, 117-118. \\ ${ }^{21}$ 1591: SzTA 7/B, 532 \\ ${ }^{22}$ 1746: SzTA 7/A, 59.
}


For the interpretation of our field investigation results, to be presented below, a piece of information from 1718 for Sâncraiu de Mureş is highly important: namely that these millraces were created - perhaps using earlier terrain features - by digging. ${ }^{23}$ According to the $17^{\text {th }}$ century documents the Mureş flood plain - just as already during the late Middle Ages - was essentially unwooded, interspersed by poplars, lindens, groves, fruit trees (plum), hemp gardens, fields, cattle pastures, ploughfields and a fish pond. The millrace on the lands belonging to Nazna (Náznánfalva) powered, in addition to the flour mills, a fulling mill as well. ${ }^{24}$ Larger oak forests in the $17^{\text {th }}-18^{\text {th }}$ century are only recorded in the hills on the northern edge of the villages in question. This picture - of wet fields on the Mureş flood plain and smaller forests on the farther, northern hills - is also clearly reflected by the First Military Survey (Fig. 3a).

The other characteristic of the area under investigation is the appearance of smaller settlements with names ending in '-szeg', which developed between larger villages dating from the Árpád period. Although there are no surviving historical or archaeological sources from the time of their formation and their early periods, we suspect that they date to much earlier than the $16^{\text {th }}-17^{\text {th }}$ centuries, when they appear in written records. Egerszeg already appears in 1448, and Remeteszeg carries in its name the memory of the medieval Pauline hermits' possessions here (remete $=$ hermit), from prior to the mid- $16^{\text {th }}$-century dissolution of the monastery. The clarification of the details requires further field investigation.

The above made it stand to reason that we should base our environmental archaeological analysis of the Sâncraiu de Mureş area on the sediment analysis of a fish pond with medieval origins, or on the millraces mentioned in the archival sources. The remains of a medieval fish pond could not be unequivocally identified in the area under investigation. Still clearly discernible today in the terrain, however, is the millrace, which branched off from the main course south of Hídvég (a village that has merged with Târgu Mureş) and, running roughly east-west, reached the southern edge of Sâncraiu de Mureş, then, continuing west, came to the southern border of Nazna (Náznánfalva), then, turning south, returned to the main watercourse. At the time of the First Military Survey the millrace was still in working order, powering a watermill at the southern edge of Sâncraiu de Mureş and Nazna respectively (Fig 3a). During the modern period it became filled up gradually. Its course is now indicated only on satellite images by the brighter-coloured and taller vegetation of its area (Fig. $2 b$ ).

\section{Environmental archaeological methods}

The studied $1.6 \mathrm{~m}$ long sediment core was recovered from the central part of the lakebed (Fig. 2) using a modified $1 \mathrm{~m}$ long 'Russian corer' with steel bars. ${ }^{25}$ The lithostratigraphical description of the profiles followed the system of Troels-Smith (1955). The grain size analysis of the samples (42 grains-size intervals between 0,0001 and $0,5 \mathrm{~mm}$ ) was performed using the laser-sedigraph method. ${ }^{26}$ For LOI examination sub-samples were taken at every $2 \mathrm{~cm}$ intervals and the commonly used loss on ignition method was applied. ${ }^{27}$ The element composition of the water solutions was examined with a PerkinElmer AAnalyst 100 atomic absorption spectrophotometer. ${ }^{28}$ The environmental magnetic analyses were carried out on bulk samples at a resolution of $2 \mathrm{~cm}$. Prior to the measurement, the weight of all individual samples was measured, and then each sample was crushed using a glass mortar. The samples were then oven-dried at $40^{\circ} \mathrm{C}$ for 24 hours. The magnetic susceptibilities were measured at a frequency of $2 \mathrm{kHz}$ using an MS2 Bartington magnetic susceptibility meter with a MS2E high-resolution sensor. ${ }^{29}$

The sequence was sampled for pollen at 1-2-cm intervals. Samples of $1 \mathrm{~cm}^{3}$ wet sediment were prepared for pollen analysis in the pollen laboratory of the Department of Geology and Palaeontology at Szeged University using standard methods and micro-sieving at $10 \mu \mathrm{m} .{ }^{30}$ Lycopodium spore tablets of known volume were added to each sample to work out pollen concentrations. ${ }^{31}$

The core was analysed at $4 \mathrm{~cm}$ intervals for macrofossils. The studied subsamples were $1 \mathrm{~cm}$ thick. Sample volume was measured by displacement of water. The samples were disaggregated if necessary and wet-sieved with

\footnotetext{
23 1718: SzTA 7/A, 341.

${ }^{24}$ 1616: SzTA 7/B, 532.

25 SÜMEGI 2001.

${ }^{26}$ SÜMEGI et al. 2015.

${ }^{27}$ DEAN 1974.
}

\footnotetext{
${ }^{28}$ DÁNIEL 2004.

${ }^{29}$ SÜMEGI et al. 2013.

${ }^{30}$ BennetT-Willis 2001.

${ }^{31}$ STOCKMARR 1971.
} 
a $250 \mu \mathrm{m}$ mesh prior the analysis of the fossil content. Remains were systematically picked out from the residues under a stereomicroscope, identified using reference collections and identification keys and counted. ${ }^{32}$ The quantitative description of macrofossil community was carried out using a modified version of the QLCMA (semi-quantitative quadrate and leaf-count macrofossil analysis) technique of Barber et al. (1994). In the diagrams, the total number of seeds relates to $10 \mathrm{~cm}^{3}$ sediment, while other macrofossil components are expressed as concentrations (piece $\mathrm{cm}^{-3}$ ). The plotting of the sedimentological, macrobotanical and geochemical data were done running psimpoll. ${ }^{33}$

\section{PALAEOENVIRONMENTAL RECONSTRUCTION}

The Mureş river originates in the Giurgeu (Gyergyó) Basin in the Eastern Carpathians. The length of the river in Romania is $761 \mathrm{~km}$, making it the longest river in Romania, the source area of which is inside the country. Along with its 797 tributaries, the total length of watercourses in its river basin reaches $10,800 \mathrm{~km}$, a density of $0.39 \mathrm{~km} / \mathrm{km}^{2}$ in a drainage basin of $27,890 \mathrm{~km}^{2}$. The upper section of the river runs between the Giurgeu Basin and the Toplița (Maroshévíz)-Deda (Déda) gorge to Deda. The middle section flows through the middle of the Transylvanian Basin, the Transylvanian Plain, and the lower section begins at Lipova (Lippa). ${ }^{34}$ Its surface runoff in the upper section of its drainage basin is $\sim 5-101 / \mathrm{s} / \mathrm{km}^{2}, 3-5$ in the middle section and less than $1 \mathrm{l} / \mathrm{s} / \mathrm{km}^{2} .{ }^{35}$ The Mureş displays mountain-river characteristics, with an average discharge of $60 \mathrm{~m}^{3} / \mathrm{s}$ in its middle section at Târgu Mureş (Marosvásárhely). In the middle section there is an approximately 175 -fold difference between the maximum and minimum discharge (Table 1).

Table 1. Mureş river discharge data ${ }^{36}$

\begin{tabular}{|l|l|l|l|}
\hline Location & Average discharge $\left(\mathrm{m}^{3} / \mathrm{s}\right)$ & Maximum measured discharge $\left(\mathrm{m}^{3} / \mathrm{s}\right)$ & Minimum measured discharge $\left(\mathrm{m}^{3} / \mathrm{s}\right)$ \\
\hline Glodeni (Marossárpatak) & 37.4 & 1210 & 4.22 \\
\hline Alba Iulia (Gyulafehérvár) & 107 & 2450 & 13.9 \\
\hline Arad (Arad) & 185 & 2320 & 22.6 \\
\hline
\end{tabular}

We studied the filled-up paleochannel of the Mures in the Holocene-age higher floodplain, on terrace $\mathrm{I} / \mathrm{b}$, at the edge of Sâncraiu de Mureş/Nazna (N 46³2'15,00" E 2330'40,24”), 300 metres above sea level (Fig. 2). This filled-up oxbow lake also appears on old maps, including the First Austrian Military Survey map of 1782; it can also be seen on the Second Austrian and the 1943 Hungarian Military Survey map as a marshy area (Fig 3). Currently, the filled-up oxbow lake is covered with weedy patches of tall sedge vegetation and a disturbed pasture is located in its vicinity. There are settlements and plough lands in the investigated area, while the expanding industrial zone of Târgu Mureş (Marosvásárhely) has reached the area as well. On the unforested territory only a few willow groups appear along the river Mureş.

On the course of the former riverbed - currently a disturbed pasture - the bore (Fig 2) reached the base with a fluvial sand layer at $120 \mathrm{~cm}$. In the undisturbed core sequence, we found the following layers. At $120 \mathrm{~cm}$ we reached a brownish-grey fine middle sand (Ga4) layer; between 120 and $90 \mathrm{~cm}$ we found significant amounts of slightly carbonate, burnt, as well as non-carbonised, degradofusinited decaying oak (Quercus) pieces in the brownish-grey sandy silt sediment (Ag2Ga2). Based on the composition of the sediment, this layer formed under active oxbow lake conditions, when the analysed paleochannel still had a rather intensive connection with the living riverbed, but would at times already be cut off from flowing water. This paleohydrological stage is indicated by the greyish-brown, thin silt laminae with a more significant clay content at the base of the core sequence. We used these thin layers and bands with a finer granulometric composition during the pollen analysis. We removed from the noncarbonised wood remains a piece weighing $2 \mathrm{~g}$ from a depth of $119-120 \mathrm{~cm}$ for radiocarbon analysis (Fig. 4). Between 90 and $60 \mathrm{~cm}$ the sand content significantly decreased, appearing in the form of sandy lenses and bands, while most of the layer was made up of yellowish-brown clayey silt. The facies of this layer, due to the thin sandy layers,

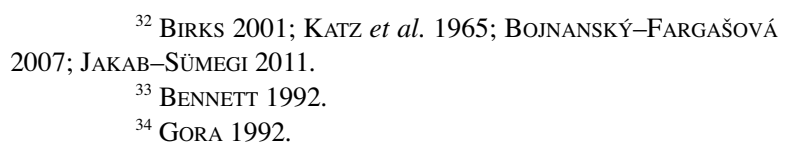

Acta Archaeologica Academiae Scientiarum Hungaricae 71, 2020

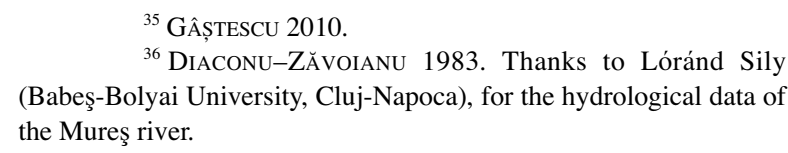

${ }^{36}$ Diaconu-Zăvoianu 1983. Thanks to Lóránd Sily (Babeş-Bolyai University, Cluj-Napoca), for the hydrological data of the Mureş river. 

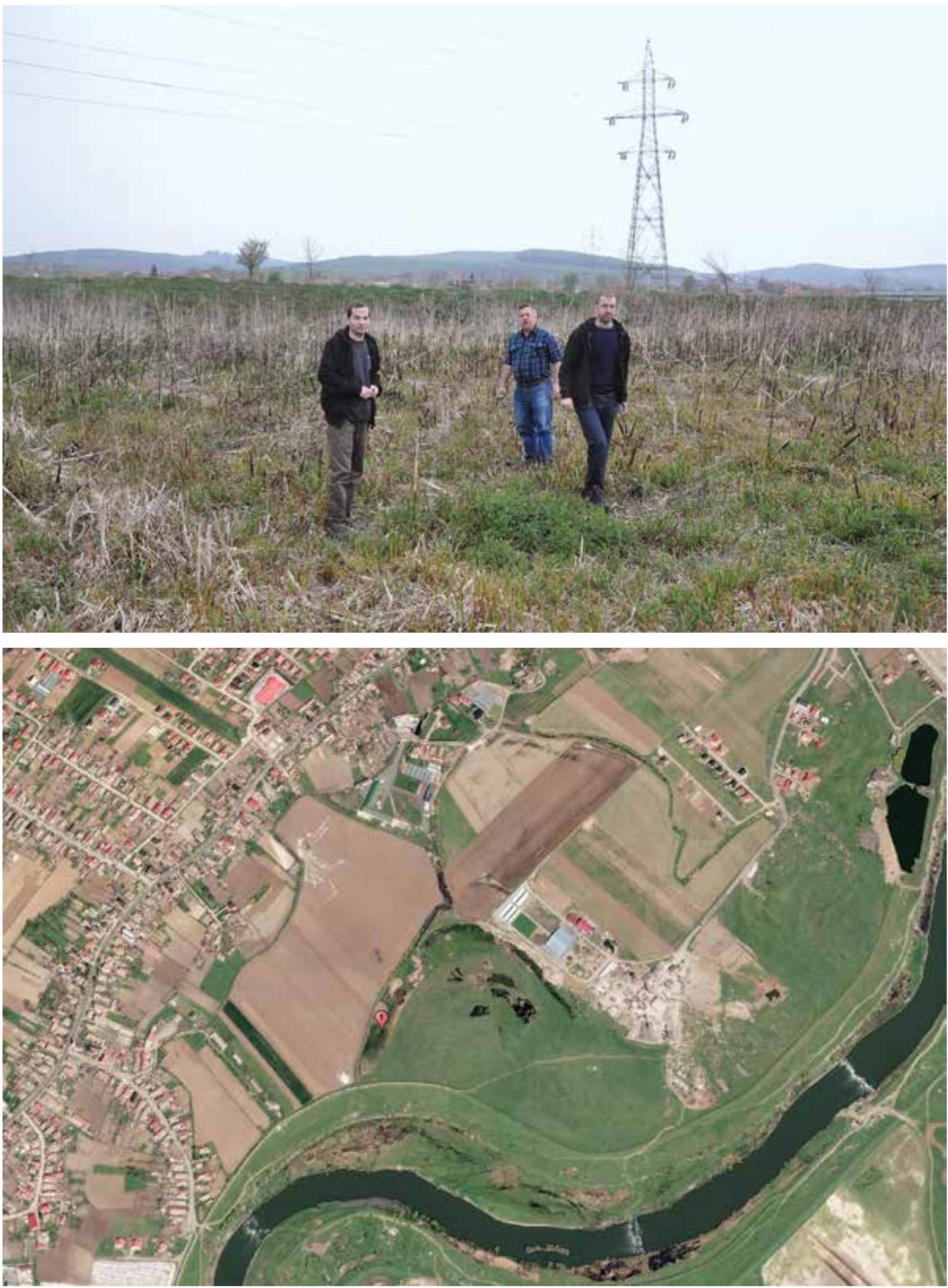

Fig. 2. a: Sâncraiu de Mureş/Nazna (Náznánfalva), the location of drilling in the field; b: The filled-up oxbow lake in the Mureş floodplain under investigation (the satellite image was taken in 20/04/2013). Clearly discernible in the image, captured in the spring, is the current trace of the former millrace bifurcating south of the settlement, with the coring point location indicated 


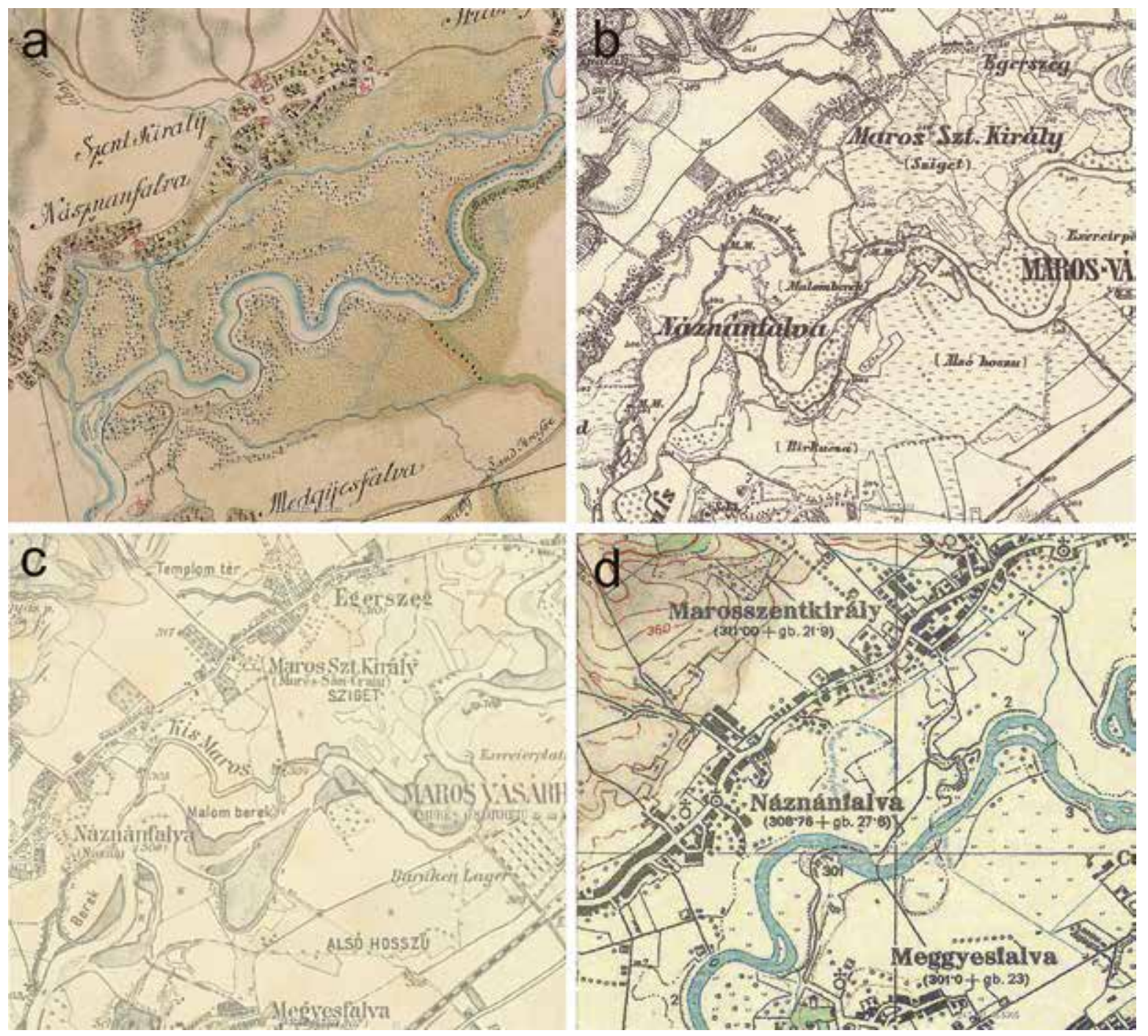

Fig. 3. The surroundings of the area under investigation on Military Survey Maps (a: 1769-1773; b: 1853-1858; c: 1869-1887, d: 1943). ${ }^{37}$

The $18^{\text {th }}-19^{\text {th }}$-century maps also indicate watermills along the former watercourse Kis- or Kicsi-Maros (Small or Little Mureş)

showed a banded, laminated structure. Based on the sedimentary structure, the oxbow lake was completely cut off from the active riverbed of the Mureş. Between 30 and $60 \mathrm{~cm}$ sand content is wholly reduced. In this horizon developed a yellowish-brown, carbonated, clayey silt layer with significant organic matter content. A significant part of the organic matter content consisted of plant remains, which could also be observed macroscopically in the core sample. The clay content appeared in bands, in flame-shaped structures. This change in the composition of the sediment suggests an intense soil erosion around the oxbow lake along due to the strong human impact, in a wet climatic phase. Between the surface and $30 \mathrm{~cm}$ below was dark brown, pedogenically altered silty clay. The part closer to the surface was highly mixed, presumably connected with modern-period animal husbandry. The investigated site has been used for the past 200 years as pasture for the Sâncraiu de Mureş (Marosszentkirály) and Nazna (Náznánfalva) herd. The mixing of the layers was likely caused by stomping and wallowing animals.

The radiocarbon analysis of an oak (Quercus) wood remain from 119-120 cm (Direct AMS/Seattle, D-AMS-016722) gave us $817+/-21$ uncal BP as the result (Fig. 4). Based on the calibration, ${ }^{38}$ the analysed sample

${ }^{37}$ TIMÁr et al. 2010.

Acta Archaeologica Academiae Scientiarum Hungaricae 71, 2020
${ }^{38}$ REIMER et al. 2013. Thanks to Krisztián Oross (Research Centre for the Humanities, Institute of Archaeology) for the calibration of the measurement. 


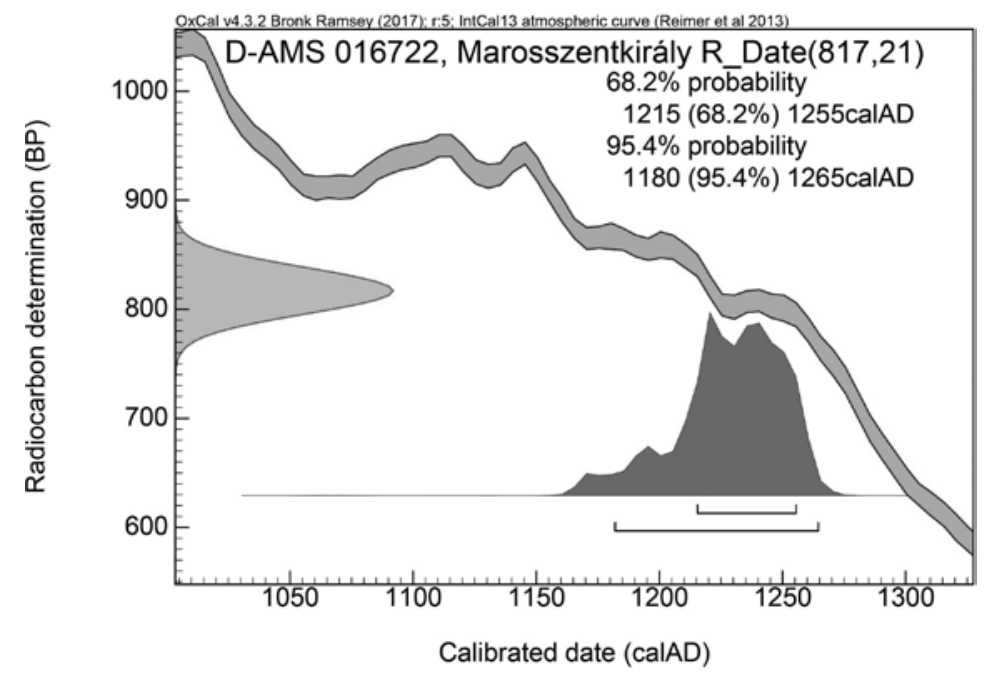

Fig. 4. Sâncraiu de Mureș (Marosszentkirály), the radiocarbon analysis of the oak (Quercus) wood residue from the core sample

comes from the period 1180-1265 cal AD years $\left(2\right.$ o $^{\circ}$. This means, that in the second half of the Árpád period $\left(12^{\text {th }}-13^{\text {th }}\right.$ centuries $)$, the oxbow lake as an open paleohydrological system was still connected to flowing water. Its slow filling-up likely began in the $13^{\text {th }}$ century. In the layer containing the wood remains there were also oak bud scale remains, which suggests that the analysed wood remains were most likely local and not old driftwood washed away from elsewhere.

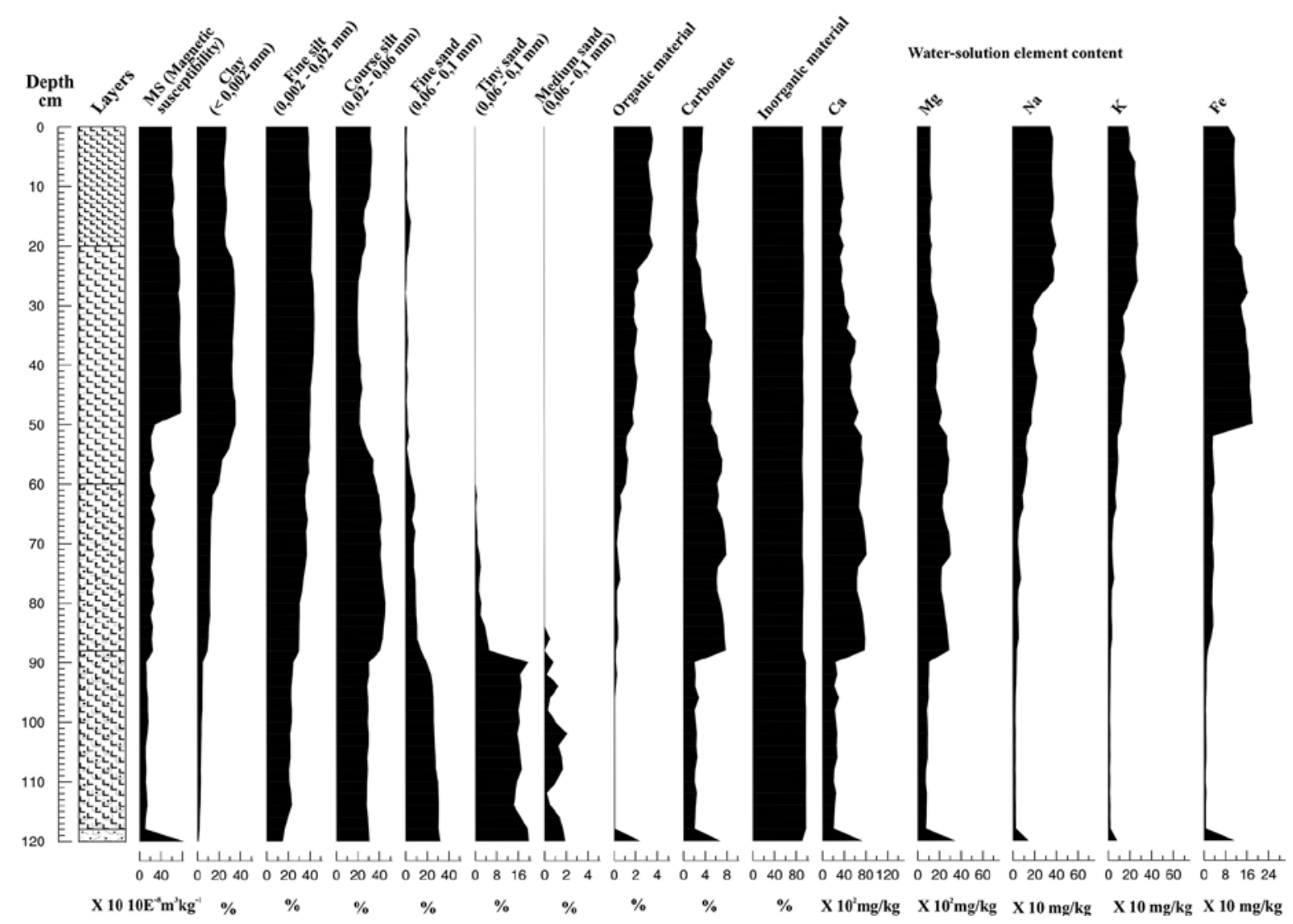

Fig. 5. The results of the sedimentological and geochemical analysis of the core sequence from Sâncraiu de Mureş (Marosszentkirály) 
Based on the magnetic susceptibility results, the oxbow lake system formed a catchment basin, gradually becoming filled up with sediments. On samples from the layers of the base with higher sand and coarse silt content we detected relatively less significant signs of magnetic susceptibility. The rising magnetic susceptibility values show correlation with the increasing organic matter, clay and water-soluble Fe and Mn content. Accordingly, the MS values increase in the so-called pelitic (rich in organic matter, clay and fine silt) sediment layers, in a $50 \mathrm{~cm}$ thick layer below the surface. Most likely, for the past 200-300 years the investigated oxbow lake had been completely cut off from the flowing water system, with stagnant water inside during a large part of the year, while significant quantities of sediment were deposited in the bed. As a result, a reductive environment developed in the paleochannel, and significant quantities of water-soluble iron $(\mathrm{Fe})$ and manganese $(\mathrm{Mn})$ entered the pelitic sediment. The lower MS values can be tied to a well-oxygenated oxbow lake connected to flowing water, and the more significant MS values to stagnant water conditions. ${ }^{39}$

The changes in the granulometric parameters, sand fraction, coarse silt, fine silt and clay fraction show a similar trend. In the base, the various sand fractions and inorganic matter content dominated (between 120 and $90 \mathrm{~cm}$ ), then the ratio of the coarse silt fraction and carbonate content increased (between 90 and $50 \mathrm{~cm}$ ). The washed-in coarse silt, rich in carbonate, can be connected with flowing water and later open oxbow lake conditions. Between $50 \mathrm{~cm}$ and the surface, the carbonate content decreased, the clay, fine silt and organic matter content gradually increased, a pelitic sediment layer developed. Tied to this trend connected with the oxbow lake gradually filling up and becoming marshy is the change in the water-soluble element content. Of these the water-soluble Ca and $\mathrm{Mg}$ maximum, connected with the carbonate system, can be connected with the formation of the open oxbow lake environment. The water-soluble $\mathrm{Fe}$ and $\mathrm{Mn}$ maximum, accumulating in a reductive environment, were connected with the pelitic sediment. The maximum of water-soluble $\mathrm{Na}$ and $\mathrm{K}$ was found in parts of the pelitic sediments closer to the surface. This was probably due to the salination on the surface of the oxbow lake's drying sediment as well as the flow and precipitation of $\mathrm{Na}$ and $\mathrm{K}$ salts dissolved in water towards the surface (Fig. 5).

To uncover the connection between medieval (and early-modern) communities and the Mureş floodplain, from the core sequence we took samples every $2 \mathrm{~cm}$ for pollen analysis and every $4 \mathrm{~cm}$ for macrobotanical analysis. For the macrofossil analysis we examined samples of 4-8 cm, ${ }^{3}$ from parts between 90 and $2 \mathrm{~cm}$ below ground. In the sample 40 different peat component and macrofossil taxa were found.

We supplemented the fundamental literature on pollen analysis necessary for the vegetation reconstruc$\operatorname{tion}^{40}$ with works on individual vegetation types and indicator elements, including weed vegetation elements. ${ }^{41}$ These publications formed the scientific basis of our reconstruction. Even though oxbow lakes are not ideal sites for palaeoenvironmental analysis ${ }^{42}$ based on the latest analyses of oxbow lakes,${ }^{43}$ it appears we can also get a realistic picture from the paleoecological analysis of these sediment-accumulation systems.

Before going into the detailed analyses, a few theoretical considerations, also significant for reflecting on the expected results, must be taken into account. What we mean, first of all, is that a pollen-based approach to the relationship between humans and environments of various historical periods is by no means a simple task. After all, the identification of the pollen material is not easy, even in the case of cultivated plants. ${ }^{44}$ These difficulties in identification apply all the more in the case of the pollen of plants considered to be weeds in the areas in question. ${ }^{45}$ After all, some of the weeds which are spread by human land use are native to Central Europe and the Carpathian Basin (e.g. Plantago lanceolata); hence we cannot automatically take their appearance to indicate anthropogenic impact. ${ }^{46}$

A further problem is caused by the phenomenon of long-distance transport,${ }^{47}$ which appears especially in alluvia, chiefly the oxbow lake systems of alluvia with flood-free banks. Here, in addition to the pollen carried by wind, the accumulation of pollen collected by the water from the entire catchment of the river, too, may be rather significant. ${ }^{48}$ In such areas, pollen deposited, then washed away, then deposited again in the Holocene layers are to

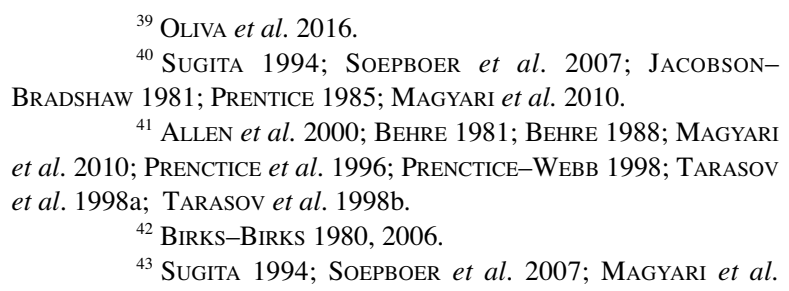

1988.

${ }^{44}$ Firbas 1937; Beug 2004; ANDERSEn 1979; Dickson

${ }^{45}$ MAgYari 2011; MAgYari et al. 2010.

${ }^{46}$ BeHRe 1988; BEHRE 2007; BeHRe 2008.

${ }^{47}$ E.g. Gregory 1978; Huelmroos 1991; Behre 2007; BEHRE 2008

${ }^{48}$ FALL 1987; SÜMEGI et al. 2013; SÜMEGI-BODOR 2000

2010, 2012. 
be especially expected. ${ }^{49}$ Hence we cannot consider oxbow lake systems in actively-developing alluvia to be ideal sites for gathering pollen. ${ }^{50}$ Moreover, the reconstruction of vegetation history and human impact on the environment is also complicated by further uncertainty factors. ${ }^{51}$

In order to distinguish between wheat, barley and oat ${ }^{52}$ outstandingly good pollen retention is necessary. This is primarily possible in geological layers with significant organic matter content, especially in peat. In the Sâncraiu de Mureș (Marosszentkirály) samples, barely 4-5\% of cereals could be identified, using a phase-contrast microscope, as Triticum type, Triticum-Avenna type and Hordeum type material. As a result, barley, wheat and oat could be identified in almost all samples, but for a quantitative evaluation, statistical analysis and a comprehensive analysis of cereal composition the pollen preservation was not suitable.

Turning to pollen analysis: the topmost $18 \mathrm{~cm}$-thick sediment section did not contain evaluable pollen material; the 52 samples, however, from the lower layers proved to be productive. Between 120 and $18 \mathrm{~cm}$ we were

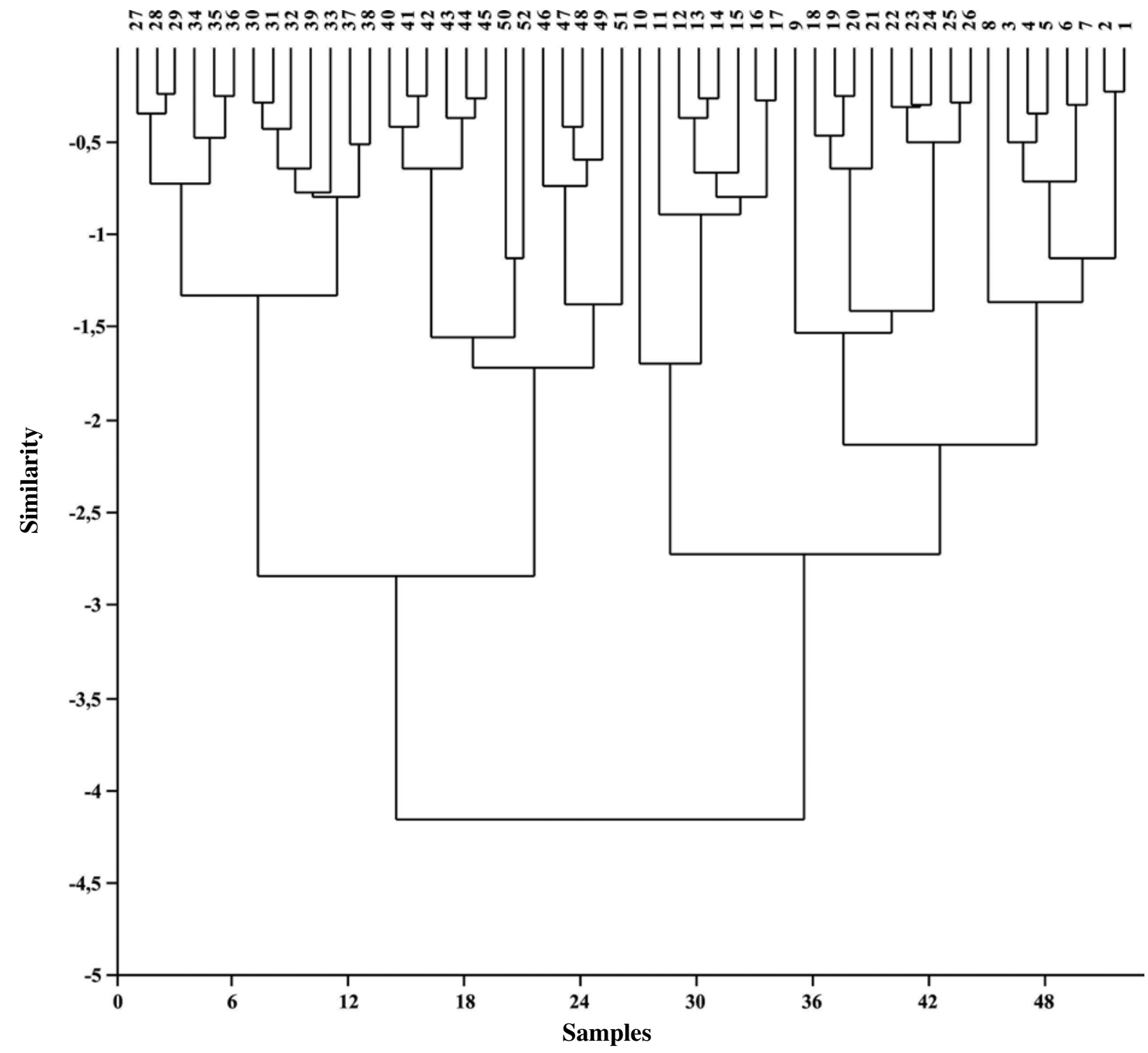

Fig. 6. The results of the cluster analysis based on pollen distribution from the Sâncraiu de Mureş (Marosszentkirály) oxbow lake sample

${ }^{49}$ SÜMEGI-BOdOR 2000.

${ }^{50}$ BIRKS-BIRKS 1980; FALL 1987.

${ }^{51}$ SÜMEGI-BODOR 2000.
${ }^{52}$ Firbas 1937; Beug 2004; ANDERSEN 1979; Dickson 1988. 


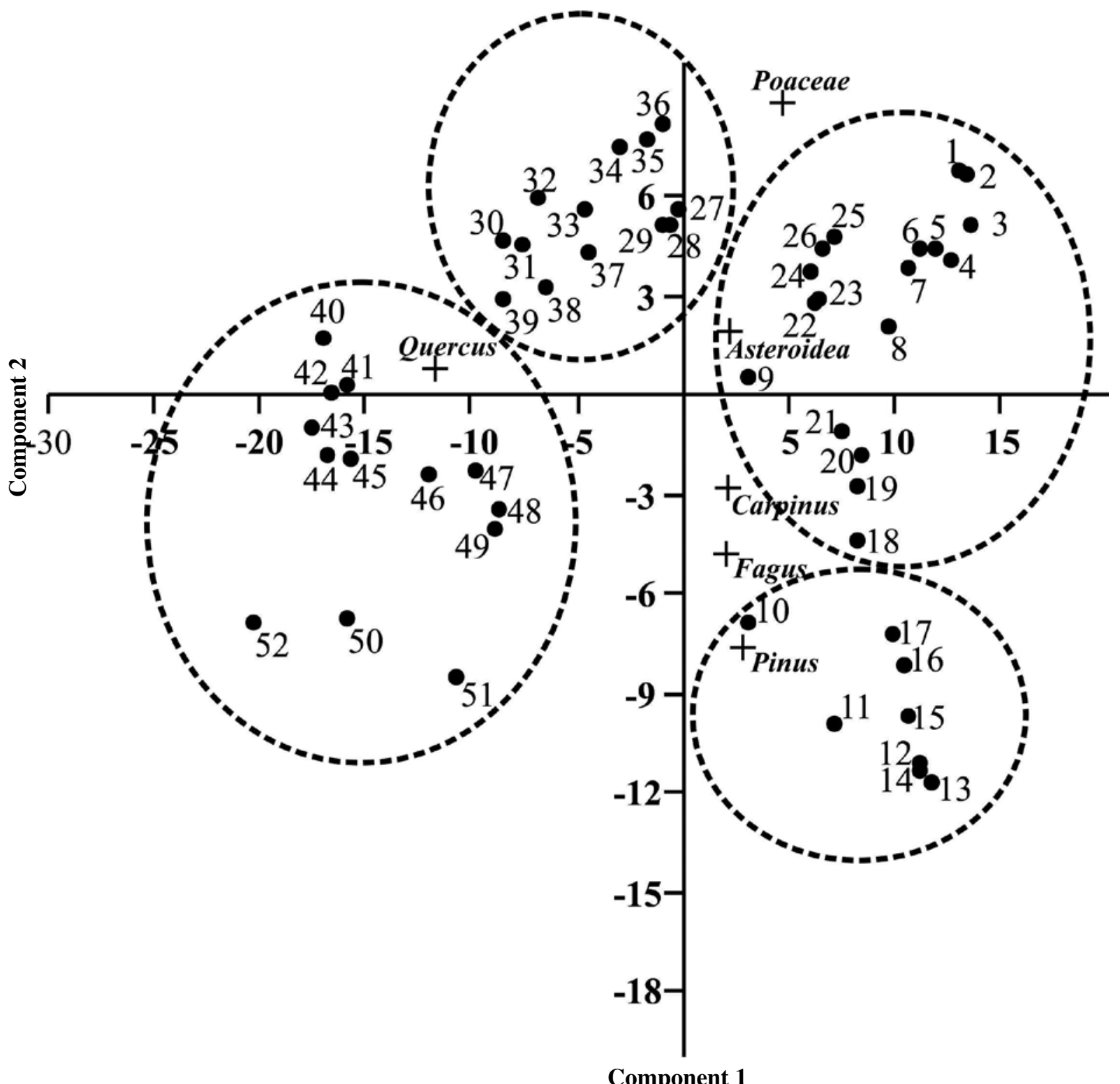

Fig. 7. The results of the principal component analysis (biplot) based on pollen distribution from the Sâncraiu de Mureş (Marosszentkirály) oxbow lake sample

able to detect 66 pollen and spore taxa; based on the distribution of pollen taxa, we performed a cluster analysis (Fig 6) as well as a principal component analysis (Fig 7).

Based on the cluster analysis and the principal component analysis we can see five local pollen zones, corresponding to changes in pollen composition. ${ }^{53}$ Principal component analysis (PCA) and cluster analysis were used to identify the major gradients both in the terrestrial and wetland pollen data. The PCA biplot of Sâncraiu de Mureş (Marosszentkirály) core pollen assemblage samples is showing sample (black circle) and taxon (cross) scores together. Principal component biplots of wetland and terrestrial pollen spectra from Mureș valley with sample scores and component loadings of the most important 26 pollen taxa (cross) plotted on the first and second principal axes. The analysis included 51 fossil samples (black curves). The first two principal components accounted for $71 \%$ and $21 \%$ of the total variance, respectively, and they are plotted in Fig. 7 together with the taxon scores. Concerning the

${ }^{53}$ BIRKS-GORDON 1974; BIRKS-GORDON 1985. 
taxon scores, the most significant variance appeared between Poaceae and Pinus-Carpinus-Fagus on the first component axis. These taxa behaved similarly along the second component axis, however, differed from Quercus and Asteroidea. The cluster analysis and PCA suggest that slow climatic change formed in the Mureş valley during last 900 years and Qeurcus dominated gallery forest changed to Fraxinus - Fagus predominated gallery forest. All the pollen composition and statistic data indicate there were primary Poaceae covered large-scale open vegetation on the alluvial surface of Mureş river from the Middle Ages to the early modern period. Although human impact can be seen already in the pollen sequence of Sâncraiu de Mureş (Marosszentkirály), PCA analyses show greater human effects in the investigated sequence (Fig. 6-7).

The presence of hardwood gallery forests is also supported by the presence of ivy (Hedera) and hazel (Corlyus). In addition to the hardwood gallery forest, a softwood (consisting of willow, birch and alder) gallery forest also appeared. The AP (Arboreal pollen) / NAP (Non-arboreal pollen) ratio was around 70:30 in this phase (Fig. 8-9). Based on this, the paleochannel was surrounded directly by a closed forest; and at the edge of the bed, and in the bed, likely grew horsetail, bulrush, reed and sedge (Fig. 10). Beyond the gallery forest zone, on the higher part of the Mureş river alluvium, on the ice-age terrace levels, by now probably already lay pastures and ploughlands.

The joint appearance of walnut (Juglans) and plum (Prunus) (Fig. 8) indicates the presence of horticulture. A higher ratio of weeds (Fig. 9) indicates the presence of roads, settlements, pastures, meadows, fields and ploughlands, the patchy and non-contiguous transformation of some 5\% - maximum 10\% - of the river valley ecosystem's territory. Aside from the stable presence of pollen suggesting cereal production, horticulture and the presence of weeds that indicate stomping, natural fields and forests dominated at this time the area under investigation.

In this phase, dated to the second half of the Árpád period, the Mureş oxbow lake under investigation was still connected to the fluvial system during a significant part of the year. From this it also follows that a significant part of the pollen could have been mixed together during floods. If that is the case, then the above results give us a regional pollen picture instead. Then the pollen composition can be compared with the pollen material of an area of at least $10 \mathrm{~km}^{2},{ }^{54}$ and the results likely characterise the section of the middle Mureş valley between the Târgu Mureş (Marosvásárhely) area and the mouth of the Niraj (Nyárád) river. There we estimate that 5-10\% of the area was heavily impacted by humans, which suggests the presence of roads, settlements, ploughlands, fields, meadows and pastures.

Between 90 and $80 \mathrm{~cm}$ a large amount of pieces of wood, carbonised wood and ash was found, and the ratio of tree and shrub pollens (AP) significantly decreased from the 70\% characteristic of closed forests to 50-55\% suggesting forest steppe. ${ }^{55}$ We found the pollen of weeds typical for roads, areas disturbed by humans, fields, ploughlands, meadows - such as ribwort plantain (Plantago lanceolata), cornflower and Centaurea, Artemisia, Chenopodioideae, Cichorioideae, Urticaceae, dock (Rumex), Apiaceae - as well as pollens of rye (Secale) and other cereals (oat and wheat) along with hemp (Cannabis type) attesting agricultural activities. The quantity of wood and ash remains, characteristic of deforestation, reaches its peak at this time. The presence of many and varied weeds, cereals, hemp and Apiaceae indicates a firm settlement level in the area under investigation. Plant cultivation likely affected at least $10 \%$ and at most $20 \%$ of the Mureş valley, which indicates growing human population and settlement sizes. We date the samples from between 90 and $70 \mathrm{~cm}$ to the late Middle Ages. Above them, between 70 and $60 \mathrm{~cm}$, a transitional pollen level formed between the second and fourth local pollen zone in terms of both trends and composition.

The macrofossil analyses support the main findings of the pollen and geochemical analyses (Fig. 11). Below $80 \mathrm{~cm}$ the organic matter in the sample mostly consisted of unidentifiable organic matter (UOM). It is noteworthy that larger charcoal and wood remains were found here. Based on the oak bud scale (Fig. 12) and several pieces of bark found in the sample we may infer the presence of an oak forest as well as significant deforestation along the oxbow lake. In this zone we found various marsh plants - e.g. bulrush (Typha angustifolia), marsh woundwort (Stachys palustris), distant sedge (Carex distans), brown galingale (Cyperus fuscus), pale smartweed (Polygonum lapathifolium) - weeds e.g. common nettle (Urtica dioica) and a dry grassland species, the thyme-leaved sandwort (Arenaria serpillifolia). Based on the sediment composition and the macroremains, we can reconstruct an 


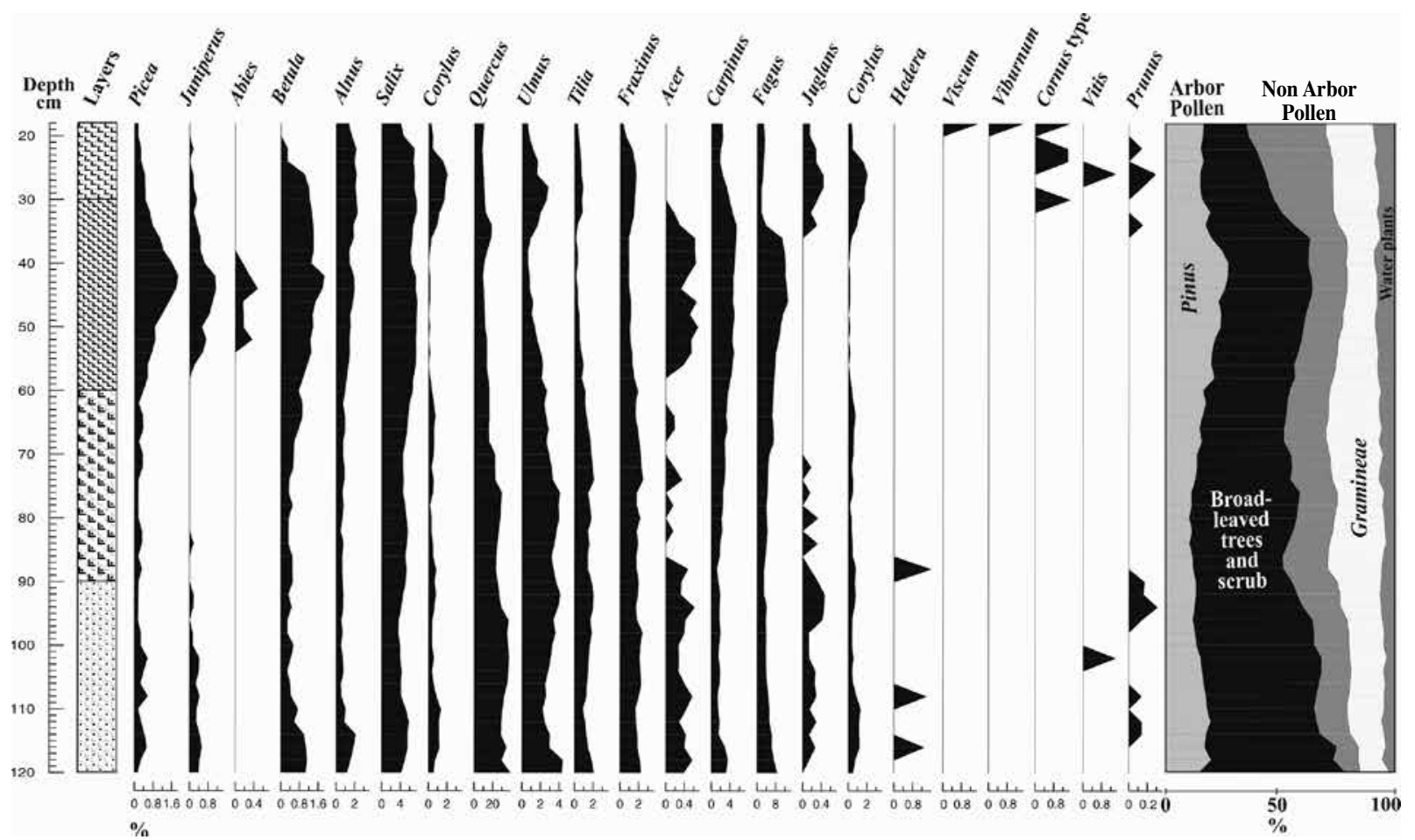

Fig. 8. Changes in Arboreal pollen (AP) ratio in the Sâncraiu de Mureş (Marosszentkirály) pollen record along the core

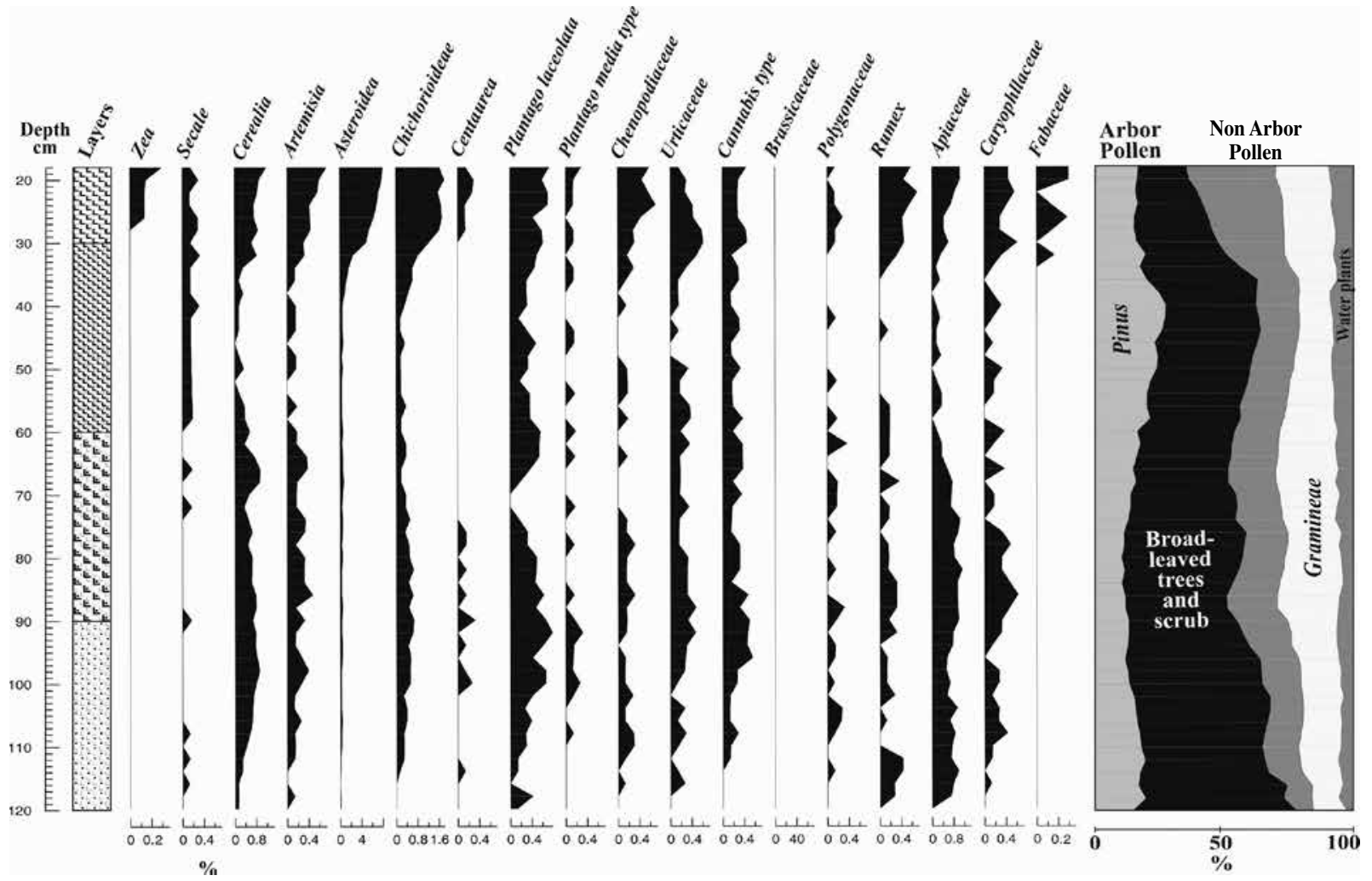

Fig 9. Changes in Non-arboreal pollen (NAP) ratio in the Sâncraiu de Mureş (Marosszentkirály) pollen record along the core 
oxbow lake with shallow water, periodically dry, covered in sparse marsh vegetation, with a sparse bulrush zone at the shoreline.

Between $60 \mathrm{~cm}$ and $30 \mathrm{~cm}$ the composition of the sediment changed, as did the pollen composition. The pollen ratio of weeds and ploughland plants decreased; the ratio of wheat, barley and oat drastically fell and rye came to the fore. The ratio of trees, especially beech, hornbeam and Scots pine strongly grew and the combined ratio of tree and shrub pollen reached $65 \%$, an increase of some 10-15\% compared to the previous layer. The decrease in the pollen ratio of species characteristic for plant cultivation and the increase of tree pollen ratio suggests declining agricultural production in the investigated area. At the same time, the changes in tree composition, the spread of beech, hornbeam and non-native Scots pine and the increasing ratio of sedges (Cyperaceae) clearly indicate strong cooling and the appearance of a wet climate period. The filling-up of the oxbow lake became faster, the paleochannel bed was likely covered in sedges, bulrush and reeds. We can link this local pollen zone to the early modern period $\left(16^{\text {th }}-17^{\text {th }}\right.$ century).

The fifth and youngest pollen horizon formed between $30 \mathrm{~cm}$ and $18 \mathrm{~cm}$ (Fig. 8-10). Based on the presence of maize pollen we date this layer to the $18^{\text {th }}$ century (Fig. 9). The pollen composition drastically changed; the ratio of trees - with the exception softwood gallery forest trees (birch, alder, willow) - strongly decreased, and the combined tree pollen ratio, including Pinaceae, fell below 50\% (Fig. 8). The pollen ratio of weed vegetation and plants indicating cereal cultivation, garden and field crops became outstandingly high (Fig. 9-10). Based on this we may infer population growth, increasing agricultural production, extensive deforestation and crop cultivation (wheat, oat, barley, rye, maize) impacting the entire middle Maros valley during the $18^{\text {th }}$ century with many ploughlands, pastures and meadows as well as cultivated gardens. Forest cover in the region did not exceed $10 \%$. Marsh environments were only found in the immediate vicinity of the oxbow lake.

One of the most important results of the macrofossil analyses is that in the upper $80 \mathrm{~cm}$ wood remains are almost completely absent. Following the deforestation, attested in the lower part of the sample, the oxbow lake's immediate vicinity remained unforested and the lake was covered by disturbed marsh vegetation. Typical species of the marsh vegetation were the lesser bulrush (Typha angustifolia), rush (Juncus sp.), reed (Phragmites communis) and sweet-grass (Glyceria sp.). The macrophytic vegetation lined the shoreline of the oxbow lake in a thin band. The central part of the lake had a sparse cover of hydrophytes with duckweed (Lemna sp.) and common stonewort (Chara vulgaris). In the water there were also planktonic organisms; and we found the remains of water fleas, ostracods as well as of a bryozoan. Water cover was likely periodical, the lakebed regularly dried out, which we can infer from the absence of hydrophytes requiring constant water cover and the from the presence of the plants typical of wet substrates vegetation. Important mud-dwelling species were the water-plantain (Alisma plantago-aquatica), the common spike-rush (Eleocharis palustris), and the celery-leaved buttercup (Ranunculus sceleratus). A striking phenomenon is the lack of swamp plants requiring constant water cover. Reeds, too, only had a subordinate role in the area. Presumably the reason for this was that the area around the bed became a pasture after the forest had been cleared, and the vicinity of the oxbow lake was likely used for grazing animals. This might be the reason also for the absence of the more demanding hydrophytes as well. The grazing and trampling animals pushed back the more demanding species, hence we only found weeds and mud-dwelling species in the sediment. In the younger part of the profile dandelion (Taraxacum sp.), dock (Rumex sp.) and white goosefoot (Chenopodium album), too, appear, which suggests an even more intensive disturbance and drying of the bed. Based on the results of the macrofossil analyses, the vegetation of the oxbow lake during the modern period was likely rather similar to what we can currently observe in the area.

\section{Mills and millraces}

The changes in land use attested by the core sample are closely connected with the fact that, already in the early period of their existence, the villages of the region established mills through the regulation of watercourses. They dug canals branching off from the Mureş riverbed with controllable water flow rates, thereby protecting these watercourses from the rapid floods of the Mureş. The mills were built along the same canal (Kis-Maros), dug taking into account the features of the terrain, for the details of the canal see below (Fig. 13). Medieval mill-sites were usually in continuous use all the way until the previous century; hence, research has shown in several areas that later 


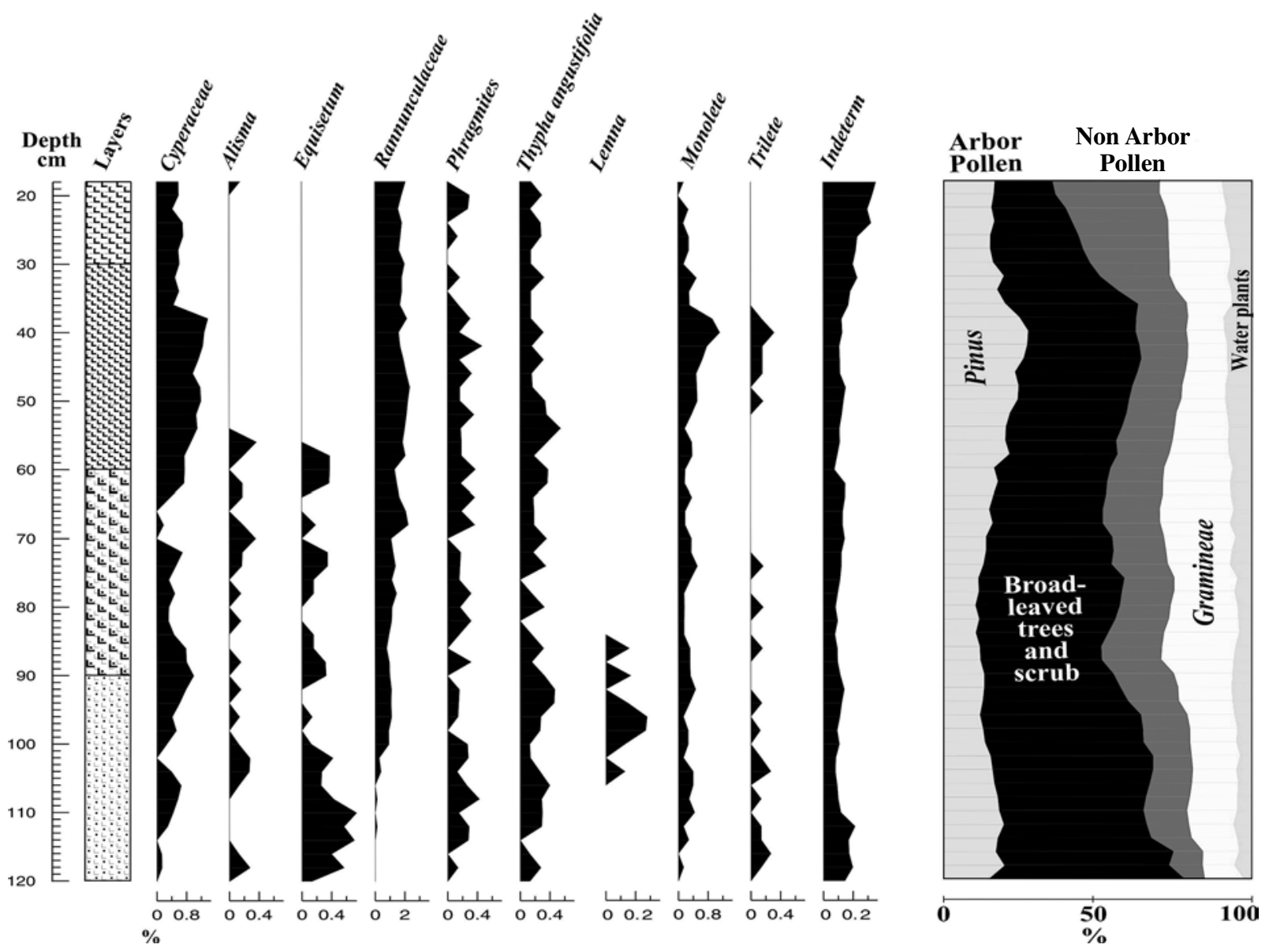

Fig 10. Changes in water plant pollens and spores in the Sâncraiu de Mureş (Marosszentkirály) pollen record along the core

mill buildings have earlier antecedents. ${ }^{56}$ In our present case at Sâncraiu de Mureş (Marosszentkirály), however, the oxbow lake analysed by coring was not a part of this millrace network, but an artificial lake connected to and fed by it, in all likelihood one of the fish ponds mentioned in the written documents. In medieval Hungary multi-purpose lakes were often connected to watermills. ${ }^{57}$ In the investigated area, however, the discharge of the Maros made it unnecessary to create reservoirs to power the watermills. Furthermore, the location of the bed, too, would not be suitable for a millpond, as it lies downstream from the mills, close to the river.

The prerequisite of operating watermills was to ensure that the level of the watercourse used to turn the waterwheel remained constant in relation to the axle, and to adjust the quantity of water in order to create the force needed to turn the wheel depending on wheel size and weight. ${ }^{58}$ This issue could be resolved simply by building floating mills or ship mills. These were already in operation during the Middle Ages on larger, navigable rivers. In the case of mills on smaller watercourses, water was carried to the mill wheel by an artificial canal. This solution provided a controlled water level even during floods; and, by narrowing the canal's cross-section, the water reaching the mill wheel could provide the required energy. ${ }^{59}$ This solution worked for centuries also on the Târgu Mureş (Marosvásárhely) section of the Mureş, as even the maps of the Third Military Survey indicate watermills along the millrace (Kis-Maros, Fig. 3).

In Fig. 13 we attempted to reconstruct the area around Sâncraiu de Mureş (Szentkirály on the map) in the period following the settlement of the Szeklers. For the reconstruction we used current satellite imagery, military maps available since the $18^{\text {th }}$ century and our own paleoenvironmental data. The greatest problem during the recon-

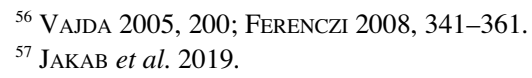

${ }^{58}$ FERENCZI 2008.

${ }^{59}$ FERENCZI 2008 


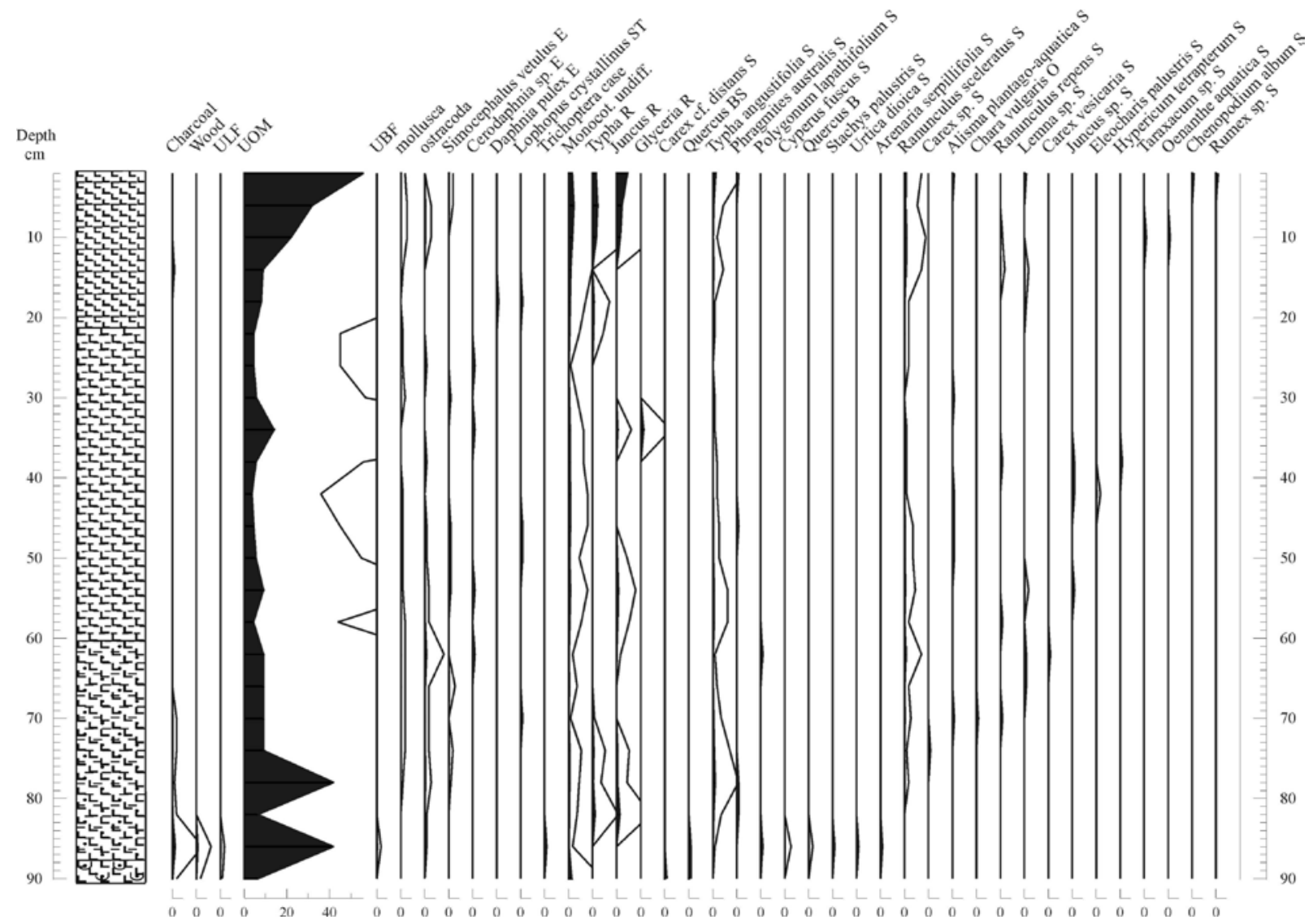

Fig. 11. The macrofossil diagram of the Sâncraiu de Mureş (Marosszentkirály) core.

The quantity of tissues and unidentifiable remains is expressed per $1 \mathrm{~cm}^{3}$ and the quantity of seeds and propagules per $5 \mathrm{~cm}^{3}$. (E: ephippium; ST: stratoblast; R: root; BS: bud scale; O: oogonium; S: seed)

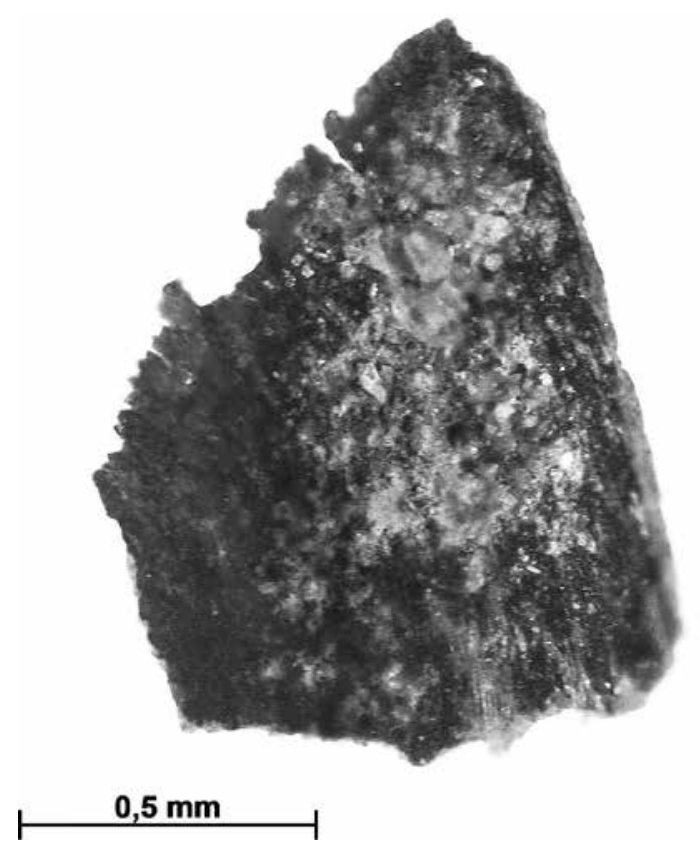

Fig. 12. Oak bud scale find from the Sâncraiu de Mureş (Marosszentkirály) core ( $13^{\text {th }}$ century) 


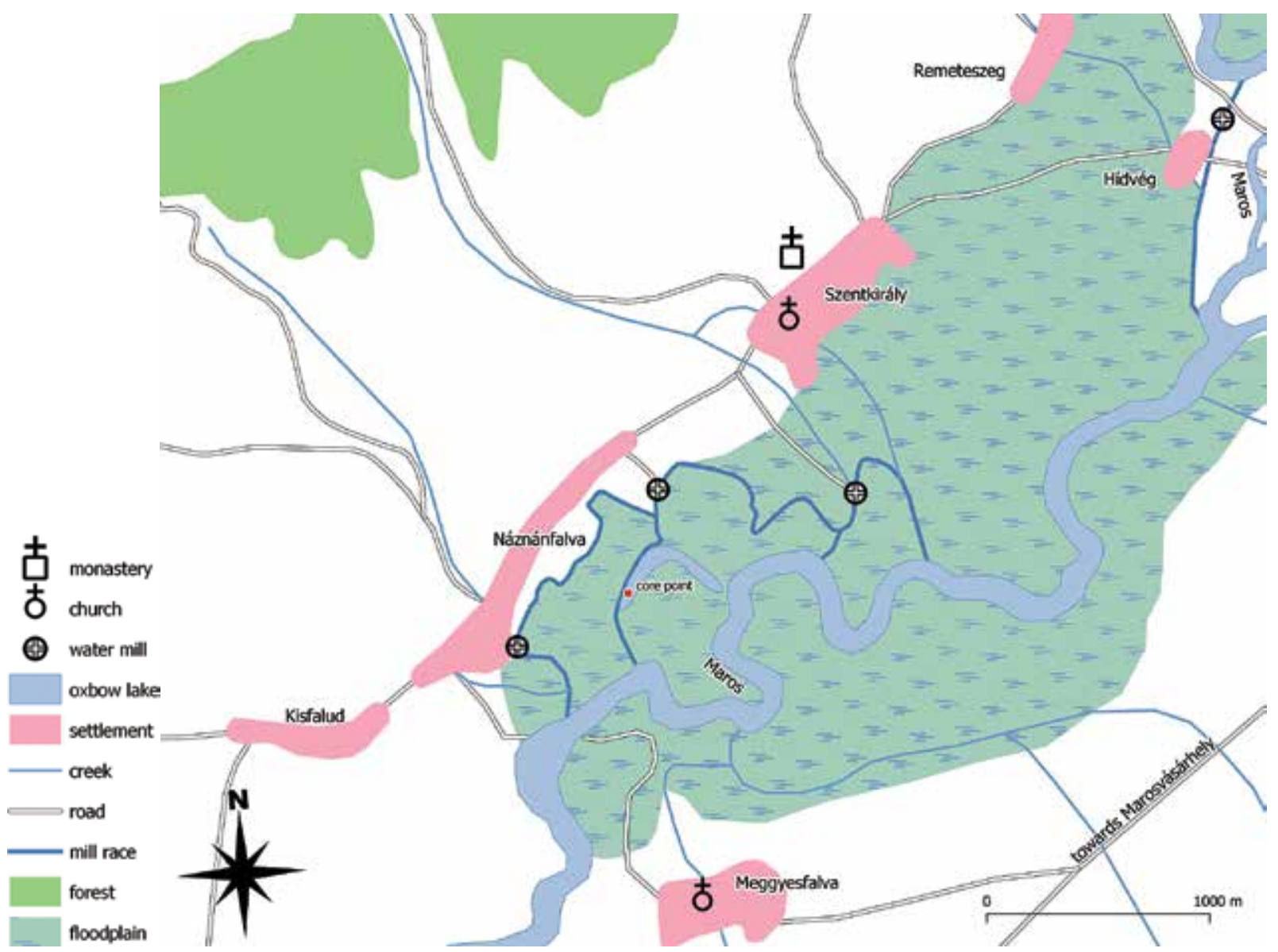

Fig. 13. Presumed land use around Sâncraiu de Mureş (Marosszentkirály) during the Middle Ages and the early modern period

struction was that in the last 100 years the landscape had changed significantly due to industrialisation and urbanisation, and it resembles little the previous conditions. The most significant change affected the path of the Mureş. Near Târgu Mureş (Marosvásárhely) the river today runs in an artificial channel. The Mureş, therefore, no longer resembles the mountain-type river seen on the $18^{\text {th }}$ century map splitting into branches and forming islands. This is primarily apparent in the area around Hídvég. Fortunately, around Sâncraiu de Mureş (Marosszentkirály) only smaller changes can be observed. Hence, during the reconstruction we georeferenced the map of the First Military Survey using the location of well-identifiable settlement features (e.g. churches and crossroads with medieval origins) as reference points. Afterwards we digitised the former bed of Mureş river, assuming that between the Middle Ages and the $18^{\text {th }}$ century the path of the low-water bed did not see a change as significant as in the $20^{\text {th }}$ century. We charted the settlements, forests and floodplains, too, based on the First Military Survey, taking into account the problem that we do not know exactly the medieval extent of these features. We located the millrace by comparing all three military surveys and the satellite imagery. The mills were charted the same way. There is, however, a serious difference between the First and Second Military Survey (Fig. 3): the position of the mill and millrace closest to Sâncraiu de Mureş is very different on the two maps. The $18^{\text {th }}$ century map shows that the millrace begins next to Hídvég and that the mill by this canal is near the village. The later maps show the mill to be farther from the village and the beginning of millrace to be closer to Sâncraiu de Mureş. It is possible that between the $18^{\text {th }}$ and $19^{\text {th }}$ century a new millrace was dug and the mill was moved; the reason for this difference, however, can also be a survey error. Unfortunately, a significant part of the land around Hídvég has been transformed; hence we could not resolve the issue in a satisfying way. For the reconstruction, therefore, we relied on the Second Military Survey in this matter. 
Most instructive on the reconstruction is the position of the mills and the millrace. Based on the map, it appears that the millrace system, created by carefully taking into account the features of the terrain, forms a logical whole. In this system the mills could be operated both together and individually, which would require a certain level of co-operation between the owners of the mills. We can further infer that to the millraces belonged a series of structures (e.g. sluice gates) to aid water management, allowing the required quantities of water to be restricted or directed to the various parts of the millrace. Filling up the oxbow lake (fishpond) connected to the millrace system with water was likely also done using a sluice gate. This millrace system, created in the Middle Ages, functioned so well that it survived up until the late- $19^{\text {th }}$ century. The Third Military Survey even shows a weir in the Mureş below the beginning of the millrace, with the help of which the appropriate, constant water level could be provided for the mills. Since such a weir was unlikely to have been built in the Middle Ages, the millraces, when water levels were low, were likely not in operation in this period.

\section{SUMMARY}

Based on archaeological data from the area under investigation and archival documents, in this western region of what became Szeklerland, the settlement pattern was substantially altered during the Árpád period. The palaeoenvironmental analysis of the filled-up bed of the Mureş near Sâncraiu de Mureş (Marosszentkirály) sheds light on the details of this transformation.

Based on the palaeoenvironmental research, a conspicuous difference from modern conditions is that this section of the Mureş valley was more wooded in the Árpád period then we would suppose based on the current state. Based on the pollen and macrofossil analyses, in the vicinity of the oxbow lake - and probably on this stretch of the Mureş valley - we can infer the presence of oak-ash-elm gallery forests in the Árpád period, which also contained other tree species, especially linden. Already in this period significant cereal production was detected in the area, which continued also in the late Middle Ages. The examined oxbow lake in the Árpád period still formed part of the natural water system of the Mureş. This Árpád period land use was substantially altered from the $13^{\text {th }}$ century, with the settlement of the Szeklers and the foundation of the nearby Pauline monastery (Fig. 13). Based on the pollen analyses, in the area under investigation the extent of cultivated land (ploughlands, gardens) substantially increased at the expense of wooded areas. In the sediment, large quantities of charcoal and wood remains indicate this significant period of deforestation. ${ }^{60}$ Geochemical, sedimentological and macrofossil analyses prove that typical lake conditions developed in the investigated oxbow lake. The lake was surrounded in a thin line of bulrush, in the bed grew sparse marsh vegetation, and in the water settled planktonic organisms. This also offered good conditions for use as a fishpond, suspected in the area based on archival documents.

The canals branching off from the Mureş riverbed were used to power mills; the main aspects of the watercourse regulation are presented in Fig. 13. Although we have relatively rich medieval and early modern sources on watermills, ${ }^{61}$ our research in Sâncraiu de Mureş (Marosszentkirály) is novel. In Transylvania this is the first documented millrace built next to a large river, which could be reconstructed using environmental archaeological methods and the date of construction of which is confirmed using radiocarbon dating.

The early modern period brought significant changes in the environment, as the climate became unfavourable (Little Ice Age). Based on the pollen analysis, we can reconstruct a small degree of forest regrowth at the expense of crop cultivation on ploughlands. The importance of more demanding cereals (wheat, oat) declined, while that of rye increased. Of course, the precise extent of this environmental change and its impact on population and economy cannot be established in detail through one, small-scale core sample. The investigated oxbow lake became filled up by the late- $19^{\text {th }}$ century and came to be used for grazing animals. By the $20^{\text {th }}$ century, the landscape had been significantly transformed. The area under investigation became part of the urban area, occupied by industrial sites of Târgu Mureş (Marosvásárhely), which was developing into a major city. Today's landscape resembles little the late-medieval or early-modern conditions. 
Our field work in Sâncraiu de Mureş (2015) was carried out in co-operation with the experts of the Mureş County Museum (Târgu Mureş, Romania); special thanks to Zalán Győrfi and Keve László. This study was supported by the Hungarian National Scientific Fund (An Environmental History of the Carpathian Basin in the Middle Ages, grant number OTKA/NKFI K-112318). The research on medieval water management was supported by the project called 'The specialize of the SZIU Campus of Szarvas research and training profile with intelligent specialization in the themes of water management, hydroculture, precision mechanical engineering, alternative crop production' (grant number EFOP-3.6.1-16-2016-00016).

\section{REFERENCES}

ALLEN et al. 2000

ANDERSEN 1979

BEHRE 1981

BEHRE 1988

BEHRE 2007

BEHRE 2008

BENKŐ 2012

BENNETT 1992

BENNETT-WiLLIS 2001

Beug 2004

BIRKS 2001

BIRKS-BIRKS 1980

BIRKS-GORDON 1974

BIRKS-GORDON 1985

BOJNANSKÝ-FARGAŠOVÁ 2007

DÁNIEL 2004

DAP

DEAN 1974

DiAconU-ZĂVOIANU 1983

DICKSON 1988

ENTZ 1996

EO

FALL 1987

FERENCZI 2008
= J. R. M. AlLEN-W. A. WATTS-B. HuntLEY: Weichselian palynostratigraphy, palaeovegetation and palaeoenvironment: the record from Lago Grande di Monticchio, southern Italy. Quaternary International 73-74 (2000) 91-110.

$=\mathrm{S}$. T. ANDERSEn: Identification of wild grass and cereal pollen. Aarbog. Danmarks Geologiske Undersoegelse 1978 (1979) 69-92.

$=\mathrm{K}$. E. BeHRE: The interpretation of anthropogenic indicators in pollen diagrams. Pollen et Spores 23 (1981) 225-245.

$=\mathrm{K}$. E. BeHRE: The role of man in European vegetation history. In: Vegetation History. Eds: B. Huntley, T. Webb. III. Springer, Dordrecht 1986, 633-672.

$=$ K. E. BEHRE: Evidence for Mesolithic agriculture in and around central Europe? Vegetation History and Archaeobotany 16 (2007) 203-219.

$=\mathrm{K}$. E. BEHRE: Collected seeds and fruits from herbs as prehistoric food. Vegetation History and Archaeobotany 17 (2008) 65-73.

= E. BENKő: A középkori Székelyföld. I-II (The Szekler Land in the Middle Ages). Budapest 2012.

$=\mathrm{K}$. D. BenNetT: PSIMPOLL - A quickBasic program that generates PostScript page description of pollen diagrams. INQUA Commission for the study of the Holocene: working group on data handling methods. Newsletter 8 (1992) 11-12.

$=$ K. D. BenNETT-K. J. Willis: Pollen. In: Tracking Environmental Change Using Lake Sediments. 3.: Terrestrial, Algal, and Siliceous Indicators. Eds: J. P. Smol, H. J. B. Birks, W. M. Last. Dordrecht 2001, 5-32.

$=\mathrm{H}$. J. Beug: Leitfaden der Pollenbestimmung für Mitteleuropa und angrenzende Gebiete. München 2004.

$=$ H. H. BIRKS: Plant macrofossils. In: Tracking Environmental Change Using Lake Sediments. 3.: Terrestrial, Algal, and Siliceous Indicators. Eds: J. P. Smol, H. J. B. Birks, W. M. Last. Dordrecht 2001, 49-74.

$=$ H. J. B. BIRKS-H. H. BIRKS: Quaternary Palaeoecology. London 1980.

$=$ H. J. B. BIRKS-A. D. GoRDON: Numerical methods in Quaternary palaeoecology in comparison of pollen diagrams. New Phytologist 73 (1974) 221-249.

$=$ H. J. B. BIRKS-A. D. GoRDON: Numerical methods in Quaternary pollen analysis. London 1985.

$=$ V. BoJnANSKÝ-A. FARgaŠovÁ: Atlas of Seeds and Fruits of Central and East-European Flora. The Carpathian Mountains Region. Springer, Dordrecht-London 2007.

= P. DÁNIEL: Methods of the five-step extraction-digestion method. Trace and microelements. In: The Geohistory of Bátorliget Marshland. Eds: P. Sümegi, S. Gulyás. Budapest 2004, 53-54.

= Documenta Artis Paulinorum. I-III. Eds: M. Tóth, G. Entz, F. Gy. Széphelyi. Budapest 1975-1978.

= W. E. DEAN: Determination of carbonate and organic matter in calcareous sediments and sedimentary rocks by loss on ignition: comparison with other methods. Journal of Sedimentary Petrology 44 (1974) 242-248.

= C. DiAconU-I. ZĂvoianu: Scurgerea apei [Flow of waters]. In: Geografia României. 1.: Geografia fizică. Eds.: L. Badea, P. Gâştescu, V. A. Velcea. Bucureşti 1983, 313-332.

= C. DiCKSON: Distinguishing cereal from wild grass pollen: some limitations. Circaea 5 (1988) 67-71.

= G. ENTZ: Erdély építészete a 14-16. században (Die Baukunst Transsilvaniens im 14-16. Jahrhundert). Kolozsvár 1996.

= Erdélyi Okmánytár-Codex diplomaticus Transsylvaniae. I-IV. Ed.: Zs. Jakó. Budapest 1997-2014.

= P. L. FALL: Pollen taphonomy in a canyon stream. Quaternary Research 28 (1937) 393-406.

= L. FERENCZI: Vízgazdálkodás a középkori Magyarországon (Water management in medieval Hungary). In: Gazdaság és gazdálkodás a középkori Magyarországon (Economy and Farming in Medieval Hungary). Eds: A. Kubinyi, J. Laszlovszky, P. Szabó. Budapest 2008, 341-361. 
FEURDEAN et al. 2013

FIRBAS 1937

GÂȘTESCU 2010

GORA 1992

GREGORY 1978

GYÖNGYÖSI 1988

HJELMROOS 1991

JACOBSON-BRADSHAW 1981

JAKAB-SÜMEGI 2011

KATZ et al. 1965

MAGYARI 2011

MAGYARI et al. 2010

MAGYARI et al. 2012

OLIVA et al. 2016

Prentice 1985

PRENTICE et al. 1996

Prentice-Webb 1998

REIMER et al. 2013

SOEPBOER et al. 2007

STOCKMARR 1971

SugITA 1994

SÜMEGI 2001

SÜMEGI-BODOR 2000

SÜMEGI et al. 2013
= A. Feurdean-J. Liakka-B. Vannière-E. Marinova-S. M. Hutchinson-V. MosburggerT. HICKLER: 12,000-Years of fire regime drivers in the lowlands of Transylvania (Central-Eastern Europe): a data-model approach. Quaternary Science Reviews 81 (2013) 48-61.

= F. FIRBAs: Der Pollenanalytysche Nachweis des Getreidebaus. Zeitschrift für Botanik 31 (1937) 447-78.

= P. GÂȘTESCU: Resursele de de apă din România. Potențial, calitate, distribuție teritorială, management [Water resources of Romania: state, quality and management]. In: Lucrările Primului Simpozion Naţional "Resursele de apă din România. Vulnerabilitate la presiunile antropice". Eds: P. Gâsstescu, P. Brețcan. Târgovişte 2010, 9-26.

= V. GoRA: Atlasul Cadastrului Apelor din România. I.: Date morfo-hidrografice asupra rețelei hidrografice de suprafață [The Atlas of Water Cadastral Survey of Romania]. București 1992.

$=$ P. H. GREGORY: Distribution of airborne pollen and spores and their long distance transport. Pure and Applied Geophysics 116 (1978) 309-315.

= G. GyÖNGYÖSI: Vitae fratrum eremitarum ordinis Sancti Pauli primi eremitae. Ed.: F. L. Hervay. Budapest 1988.

= M. HJelmroos: Evidence of long-distance transport of Betula pollen. Grana 30 (1991) 215-228.

= G. L. JACOBSON-R. H. W. BRADSHAW: The selection of sites for palaeovegetational studies. Quaternary Research 16 (1981) 80-96.

= G. JAKAB-P. SüMEGI: Negyedidőszaki makrobotanika (Quaternary macrobotany). Szeged 2011.

= N. J. KaTZ-S. V. KatZ-M. G. KIPIANI: Atlas and Keys of Fruits and Seeds Occurring in the Quaternary Deposits of the USSR. Moscow 1965.

= E. K. MAGYARI: Late Quaternary vegetation history in the Hortobágy steppe and Middle Tisza floodplain, NE Hungary. Studia Botanica Hungarica 42 (2011) 185-203.

= E. K. Magyari-J. C. Chapman-D. G. Passmore-J. R. M. Allen-J. P. Huntley-B. Huntley: Holocene persistence of wooded steppe in the Great Hungarian Plain. Journal of Biogeography 37 (2010) 915-935.

= E. K. Magyari-J. Chapman-A. S. FAirbairn-M. Francis-M. DE Guzman: Neolithic human impact on the landscapes of North-East Hungary inferred from pollen and settlement records. Vegetation History and Archaeobotany 21 (2012) 279-302.

$=$ F. Oliva-A. E. ViaU-J. BJornson-N. Desrochers-M. A. Bonneau: A 1300 year reconstruction of paleofloods using oxbow lake sediments in temperate southwestern Quebec, Canada. Canadian Journal of Earth Sciences 53 (2016) 378-386.

= I. C. PRENTICE: Pollen representation, source area, and basin size: toward a unified theory of pollen analysis. Quaternary Research 23 (1985) 76-86.

= I. C. Prentice-J. Guiot-B. Huntley-D. Jolly-R. Cheddadi: Reconstructing biomes from palaeoecological data: a general method and its application to European pollen data at 0 and $6 \mathrm{ka}$. Climate Dynamics 12 (1996) 185-194.

= I. C. Prentice-T. WebB: BIOME 6000: reconstructing global mid-Holocene vegetation patterns from palaeoecological records. Journal of Biogeography 25 (1998) 997-1005.

= P. J. Reimer-E. Bard-A. Bayliss-J. W. Beck-P. G. Blackwell-C. B. Ramsey-C. E. BucKH. Cheng-L. R. Edwards-M. Friedrich-P. M. Grootes-T. P. GuILderson-H. Haflidason-I. HajdAC. Hatté-T. J. Heaton-D. L. Hoffmann-A. G. HogG-K. A. Hughen-F. K. Kaiser-B. KromerS. W. Manning-M. Niu-R. W. Reimer-D. A. Richards-M. E. Scott-J. R. Southon-R. A. StafFC. S. M. TURNEY-J. VAN DER PLICHT: IntCal13 and Marine13 radiocarbon age calibration curves 0-50,000 years cal BP. Radiocarbon 55 (2013) 1869-1887.

= W. Soepboer-S. Sugita-A. F. Lotter-J. F. N. van Leeuwen-W. O. van der KnaAp: Pollen productivity estimates for quantitative reconstruction of vegetation cover on the Swiss Plateau. The Holocene 17 (2007) 65-77.

$=$ J. Stockmarr: Tables with spores used in absolute pollen analysis. Pollen and Spores 13 (1971) 615-621.

$=\mathrm{S}$. SUGITA: Pollen representation of vegetation in Quaternary sediments: theory and method in patchy vegetation. Journal of Ecology 82 (1994) 881-897.

= P. SÜMEGI: A negyedidőszak földtanának és őskörnyezettanának alapjai [Fundamentals of Quaternary Geology and Palaeoecology]. Szeged 2001.

$=$ P. SÜMEGI-E. Bodor: Sedimentological, pollen and geoarcheological analysis of core sequence at Tököl. In: Százhalombatta Archaeological Expedition: Annual report 1998. Eds: I. Poroszlai, M. Vicze. Szászhalombatta 2000, 83-96.

= P. SÜMEGI-S. GulYÁs-B. CsÖKmEI-D. MolnáR-U. HammbaCH-S. MarkoviC-T. Stevens: Climatic fluctuations inferred for the Middle and Late Pleniglacial (MIS2) based on high-resolution ( ca.20 y) preliminary environmental magnetic investigation from the loess profile of Madaras brickyard (Hungary). Central European Geology 55 (2013) 329-345. 
SÜMEGI et al. 2015

$\mathrm{SzOkl}$

SzTA 7/A-B

TARASOV et al. $1998 \mathrm{a}$

TARASOV et al. $1998 \mathrm{~b}$

TIMÁR et al. 2010

VAJDA 2005
= P. SÜMEGI-K. NÁFrÁDI-D. MolnÁR-Sz. SÁvAI: Results of paleoecological studies in the loess region of Szeged-Öthalom (SE Hungary). Quaternary International, 372 (2015) 66-78.

= Székely Oklevéltár [Szekler Chartulary]. I-VIII. Eds: K. Szabó, L. Szádeczky, S. Barabás. Kolozsvár-Budapest 1872-1934.

= Szabó T. Attila erdélyi történeti helynévgyüjtése. 7/A-B.: Maros-Torda megye [Collection of Transylvanian Historical Place Names by Attila T. Szabó]. Eds: M. Hajdú, K. Sófalvi. Budapest 2005.

= P. E. Tarasov-T. Webb-A. A. Andreev-N. B. Afanaseva-N. A. Berezina-L. G. BezuskoT. A. Blyakharchuk-N. S. Bolikhovskaya-R. Cheddadi-M. M. Chernavskaya-G. M. Chernova N. I. Dorofeyuk-V. G. Dirksen-G. A. Elina-L. V. Filimonova-F. Z. Glebov-J. GuiotV. S. Gunova-S. P. Harrison-D. Jolly-V. I. Khomutova-E. V. Kvavadze-I. M. Osipova-N. K. Panova-I. C. Prentice-L. SaArse-D. V. Sevastyanov-V. S. Volkova-V. P. Zernitskaya: Present day and mid Holocene biomes reconstructed from pollen and plant macrofossil data from the former Soviet Union and Mongolia. Journal of Biogeography 25 (1998) 1029-1053.

= P. E. Tarasov-R. Cheddadi-J. Guiot-S. Bottema-O. Peyron-J. Belmonte-V. Ruiz-SanchezF. A. SAADI-S. BREwER: A method to determine warm and cool steppe biomes from pollen data; application to the Mediterranean and Kazakhstan regions. Journal of Quaternary Science 13 (1998) 335-344.

= G. Timár-S. BiszaK-B. Székely-G. Molnár: Digitized maps of the Habsburg Military Surveys - overview of the project of ARCANUM Ltd. (Hungary). In: Preservation in Digital Cartography. Ed.: M. Jobst. Berlin-Heidelberg 2010, 273-283.

= T. VAJDA: Okleveles adatok Árpád-kori vízimalmainkról (Charter data on Árpádian-period mills). In: Medievisztikai tanulmányok. A IV. Medievisztikai PhD-konferencia előadásai. Eds: Sz. Marton, É. Teiszler. Szeged 2005, 193-220.

Open Access. This is an open-access article distributed under the terms of the Creative Commons Attribution 4.0 International License (https:// creativecommons.org/licenses/by/4.0), which permits unrestricted use, distribution, and reproduction in any medium, provided the original author and source are credited, a link to the CC License is provided, and changes - if any - are indicated. (SID_1) 